\title{
Review Article \\ Structures of Astaxanthin and Their Consequences for Therapeutic Application
}

\author{
Tatas Hardo Panintingjati Brotosudarmo $\mathbb{D},{ }^{1}$ Leenawaty Limantara, ${ }^{2}$ Edi Setiyono, ${ }^{1}$ \\ and Heriyanto ${ }^{1}$ \\ ${ }^{1}$ Ma Chung Research Center for Photosynthetic Pigments (MRCPP) and Department of Chemistry, Universitas Ma Chung, \\ Villa Puncak Tidar N01, Malang 465151, Indonesia \\ ${ }^{2}$ Center for Urban Studies, Universitas Pembangunan Jaya, Jl. Cendrawasih Raya B7/P, South Tangerang, 15413 Banten, Indonesia
}

Correspondence should be addressed to Tatas Hardo Panintingjati Brotosudarmo; tatas.brotosudarmo@machung.ac.id

Received 3 February 2020; Revised 24 June 2020; Accepted 29 June 2020; Published 21 July 2020

Academic Editor: Jaime Yanez

Copyright (c) 2020 Tatas Hardo Panintingjati Brotosudarmo et al. This is an open access article distributed under the Creative Commons Attribution License, which permits unrestricted use, distribution, and reproduction in any medium, provided the original work is properly cited.

\begin{abstract}
Reactive oxygen species (ROS) are continuously generated as a by-product of normal aerobic metabolism. Elevated ROS formation leads to potential damage of biological structures and is implicated in various diseases. Astaxanthin, a xanthophyll carotenoid, is a secondary metabolite responsible for the red-orange color of a number of marine animals and microorganisms. There is mounting evidence that astaxanthin has powerful antioxidant, anti-inflammatory, and antiapoptotic activities. Hence, its consumption can result in various health benefits, with potential for therapeutic application. Astaxanthin contains both a hydroxyl and a keto group, and this unique structure plays important roles in neutralizing ROS. The molecule quenches harmful singlet oxygen, scavenges peroxyl and hydroxyl radicals and converts them into more stable compounds, prevents the formation of free radicals, and inhibits the autoxidation chain reaction. It also acts as a metal chelator and converts metal prooxidants into harmless molecules. However, like many other carotenoids, astaxanthin is affected by the environmental conditions, e.g., $\mathrm{pH}$, heat, or exposure to light. It is hence susceptible to structural modification, i.e., via isomerization, aggregation, or esterification, which alters its physiochemical properties. Here, we provide a concise overview of the distribution of astaxanthin in tissues, and astaxanthin structures, and their role in tackling singlet oxygen and free radicals. We highlight the effect of structural modification of astaxanthin molecules on the bioavailability and biological activity. These studies suggested that astaxanthin would be a promising dietary supplement for health applications.
\end{abstract}

\section{Introduction}

Carotenoids are a class of bioactive natural products synthesized by plants and certain photosynthetic microorganisms. Many carotenoids are directly involved in the photosynthesis process, while others protect the host from photooxidation and related damage [1]. Astaxanthin is a carotenoid that has garnered significant interest in recent years. It is a red xanthophyll carotenoid found predominantly in marine microorganisms and animals [2,3]. Astaxanthin is ranked as the second most important carotenoid on the global market after capsanthin. Its market size exceeded US\$288.7 million in 2017 and will reach US\$ 426.9 million by 2022, dominating the carotenoid industry, with a predicted $8.1 \%$ compound annual growth rate until 2022 [4]. Natural astaxanthin has been approved as generally recognized as safe (GRAS). It can be sold as a dietary supplement and has been also approved as a food colorant (E161j) by the European Commission for use in the food and beverage industries [5].

Astaxanthin supplementation has been investigated in a broad range of clinical applications in humans and was shown to exert multiple pharmacological effects $[3,6]$. The beneficial effects of astaxanthin are often associated with its antioxidative [7-9], anti-inflammatory [10-13], and antiapoptotic properties [10, 14-17]. As demonstrated in several studies, astaxanthin stimulates the immune response, e.g., by increasing interferon and interleukin 2 production without inducing cytotoxicity [18-21]. It potentially plays a 
neuroprotective role in neurological disorders, such as brain ischemic or traumatic injury, and subarachnoid bleeding [22-28]. It also exhibits a novel cardioprotective potential suppressing homocysteine-induced cardiotoxicity by alleviating mitochondrial dysfunction and oxidative damage [29]. Furthermore, astaxanthin effectively suppresses metastasis of the colon and cell lung cancers [30-32], prevents binding of the human papillomavirus L1 protein to the human sperm membrane [33], improves stem cell potency by increasing the proliferation of neural progenitor cells [34]; prevents liver damage in carbon tetrachloride-induced toxicity [35], inhibits membrane peroxidation in human endothelial cells [36], and exerts antiaging effects [37-40]. Some in vitro and in vivo studies of the biological role of astaxanthin are presented in Table 1.

Reactive oxygen species (ROS) have attracted attention as novel signal mediators involved in the modulation of cell survival, cell death, differentiation, cell signaling, and inflammation-related factor production [42]. Large quantities of ROS are generated during mitochondrial oxidative metabolism, as well as during cellular response to xenobiotics, cytokines, and bacterial invasion [43, 44]. Cellular imbalance caused by ROS or oxidants that exceed the cellular capability to mount an effective antioxidant response is called oxidative stress. It results in macromolecular damage and is implicated in various diseases. The key function of astaxanthin as a potent antioxidant depends on its ability to scavenge singlet oxygen [45] and free radicals [46].

The ability of astaxanthin to attack active oxygen species is reportedly 10 -fold higher than that of zeaxanthin, lutein, tunaxanthin, cathaxanthin, and $\beta$-carotene, and 100-fold higher than that of $\alpha$-tocopherol [47]. The unique molecular structure of astaxanthin, the characteristics of its excited state and isomeric forms, and the tendency to aggregate in different solvents impact its biological activity and bioavailability. In the present review, we provide information on astaxanthin sources, structural diversity, and mechanism of action related to its interaction with ROS.

\section{Sources of Astaxanthin}

The natural sources of astaxanthin include green algae, bacteria, fungi, archaea, chromista, shrimp, crawfish, crabs, lobster, Antarctic krill, marine copepoda, and salmonids, as presented in Table 2.

Astaxanthin is ubiquitous in marine organisms. It is responsible for the well-known red-orange color of the skin and flesh of shrimp and crayfish, and the flesh of salmon. Crustaceans and fish cannot synthesize astaxanthin de novo, and thereby rely on the supply of astaxanthin precursors through the consumption of algae and other microorganisms [87]. Likewise, human is unable to synthesize carotenoids, and they have to be obtained from the diet. The main source of astaxanthin for humans is seafood, with salmon, for example, wild Sockeye salmon (Oncorhynchus nerka), containing the most astaxanthin (26-38 $\mathrm{mg} \mathrm{kg}^{-1}$ wet weight) [86]. The rainbow trout (Oncorhynchus mykiss) is also a good source of astaxanthin (24 $\mathrm{mg} \mathrm{kg}^{-1}$ wet weight) [86]. Currently, approximately $72 \%$ of the world's salmon production is farmed [88]. Flesh pigmentation is a key commercial trait of farmed salmon, and it is often associated with product quality. In the aquaculture sector, commercial astaxanthin food additives can account for up to $25 \%$ of feed costs [ 89 , 90]. The origin of astaxanthin sources can be monitored by high-performance liquid chromatography (HPLC) of the isomers present in the flesh. For instance, in salmon fed yeast-derived astaxanthin, the $3 R, 3^{\prime} R$ isomer is the major component, while in salmon fed synthetic astaxanthin, the $3 R, 3^{\prime} S$ isomer is abundant [91]. Of note, currently, over $95 \%$ of astaxanthin available on the market is derived synthetically from petrochemicals; on the other hand, Haematococcus pluvialis-derived natural astaxanthin accounts for $<1 \%$ of commercialized astaxanthin [92]. However, safety concerns have arisen regarding the use of synthetic astaxanthin for human consumption [93].

\section{Astaxanthin Structures}

3.1. Basic Structure and Isomers of Astaxanthin. Astaxanthin is a xanthophyll carotenoid because it contains oxygen. Astaxanthin $\left(3,3^{\prime}\right.$-dihydroxy- $\beta, \beta^{\prime}$-carotene- $4,4^{\prime}$-dione; CAS no. $472-61-7 ; \quad \mathrm{Mw}=596.8 \mathrm{~g} \mathrm{~mol}^{-1} ; \quad \varepsilon_{468 \mathrm{~nm}}=125 \times 10^{3} \mathrm{~mol}^{-1} \mathrm{c}$ $\mathrm{m}^{-1}$ in hexane) consists of two terminal $\beta$-ionone-type rings joined by a polyene chain. It has two asymmetric carbons located at the $3,3^{\prime}$-position of the $\beta$-ionone ring, with a hydroxyl group $(-\mathrm{OH})$ on either end of the molecule (Figure 1). Oxygen is present in the ring system as both a hydroxyl and a keto $(\mathrm{C}=\mathrm{O})$ group.

Astaxanthin can be esterified, which increases its solubility in the cell and makes it more stable to oxidation [94]. The hydroxy group on one or both rings can bind to different fatty acids, such as palmitic, oleic, estearic, or linoleic acid, to form mono- or diesters, accordingly. Astaxanthin also exists in a free form, i.e., with the hydroxyl group not esterified, and in a chemical complex with proteins or lipoprotein. Further, stereoisomers and geometric isomers of astaxanthin are identified [81]. Figure 1 shows three configurational isomers of the compound: two enantiomers $\left(3 R, 3^{\prime} R\right.$ and $\left.3 S, 3^{\prime} S\right)$ and a meso form $\left(3 R, 3^{\prime} S\right)$. The alga Haematococcus synthesizes mainly the $3 S, 3^{\prime} S$ isomer, which is also predominant in wild Atlantic salmon, and occurs mainly in the free form [93]. The Antarctic krill (Euphausia superba) produces the $3 R, 3^{\prime} R$ as the primary isomer [3]. Whereas the three optical stereoisomers exist in nature in variable ratios, synthetic astaxanthin is a racemic mixture of the two enantiomers and the meso form [81]. Synthetic astaxanthin contains the $3 S, 3^{\prime} S, 3 R, 3^{\prime} S$, and $3 R, 3^{\prime} R$ isomers in a $1: 2: 1$ ratio, respectively. It is not esterified, while natural astaxanthin mostly occurs in esterified form, or in a complex with proteins or lipids [81].

Astaxanthin also exists as trans and cis ( $E$ and $Z$ ) geometrical isomers (Figure 2), depending on the configuration of the double bonds in the polyene chain. All-trans astaxanthin (all$E$-astaxanthin) is the dominant isomer, although at least two cis-isomers (9-cis and 13-cis) also occur in nature, depending on the host species and body part, and are also found in synthetic preparations [95]. In rainbow trout (O. mykiss), 
TABLE 1: Biological activities of astaxanthin evaluated in vitro and in vivo, with the study model, target, and dosage specified.

\begin{tabular}{|c|c|c|c|c|c|}
\hline Model & Main effect & Dosage & Target & Disease & Ref. \\
\hline SD rat & Antioxidant & $10 \mu \mathrm{M}$ & Nrf2/ARE & $\begin{array}{c}\text { Diabetic } \\
\text { nephropathy }\end{array}$ & {$[7]$} \\
\hline C57BL/6 mice & Antioxidant & $\begin{array}{l}0.02 \% \\
(w / w)\end{array}$ & Nrf2, HO-1, BALF & $\begin{array}{l}\text { Chronic } \\
\text { obstructive } \\
\text { pulmonary } \\
\text { melanogster }\end{array}$ & {$[8]$} \\
\hline ETS mouse & Anti-inflammatory & $\begin{array}{l}40 \text { and } \\
80 \mathrm{mg} / \mathrm{kg}\end{array}$ & $\begin{array}{l}\text { p38 MAPK, NF- } \kappa \text { B-p65, PSD-95, IL-6, } \\
\text { TNF- } \alpha, \text { MDA, SOD, GSH, CAT }\end{array}$ & $\begin{array}{l}\text { Cognitive } \\
\text { impairment }\end{array}$ & [10] \\
\hline H. Pylori-free BALB/c female mice & Anti-inflammatory & $\begin{array}{l}10 \mathrm{or} \\
40 \mathrm{mg} / \mathrm{d}\end{array}$ & IFN- $\gamma$, IL-2, IL-10 & $\begin{array}{l}\text { Gastrointestinal } \\
\text { disease }\end{array}$ & [21] \\
\hline Drosophila melanogaster (fruit fly) & Antiaging & $\begin{array}{c}10 \mathrm{or} \\
20 \mathrm{mg} / \mathrm{mL}\end{array}$ & SOD1, SOD2, CAT & $\begin{array}{l}\text { No detailed } \\
\text { disease }\end{array}$ & [39] \\
\hline Wistar rat & Antiaging & $10 \mathrm{mg} / \mathrm{kg} / \mathrm{d}$ & IL- $1 \beta$, IL-10 & Brain aging & [40] \\
\hline Wistar rat & Anticancer & $15 \mathrm{mg} / \mathrm{kg} / \mathrm{d}$ & $\begin{array}{l}\text { ERK-2, NF- } \kappa \text { B-p65, COX-2, } \\
\text { MMPs- } 2 / 9, \text { AKT, ERK-2 }\end{array}$ & Colon cancer & {$[31]$} \\
\hline $\begin{array}{l}\text { Nonsmall cell lung cancer type } \\
\text { A549 and H1703 }\end{array}$ & Anticancer & $2.5-20 \mu \mathrm{M}$ & Rad51, AKT & Lung cancer & [32] \\
\hline Male $\mathrm{BALB} / \mathrm{c}$ mice & Immunomodulatory & $\begin{array}{l}0.28,1.4 \\
\quad \text { and } \\
7 \mathrm{mg} / \mathrm{kg} / \mathrm{d}\end{array}$ & IFN- $\gamma$, IL-2, Con A, LPS & $\begin{array}{l}\text { No detailed } \\
\text { disease }\end{array}$ & [18] \\
\hline HPV16-L1 & Anti-HPV & $2 \mu \mathrm{M}$ & CTB, Lyn, Tyr-P, ARC & $\mathrm{HPV}$ & [33] \\
\hline Male SPF C57BL/J mice & Antiobesity & $\begin{array}{l}0.005 \% \text { or } \\
0.01 \% / \text { diet } \\
\text { powder }\end{array}$ & $\begin{array}{l}\text { Weight gain, energy intake, fat index, } \\
\text { plasma triacylglycerol and cholesterol, liver } \\
\text { triacylglycerol and cholesterol }\end{array}$ & Obesity & [41] \\
\hline Wistar rat & Neuroprotective & $10 \mathrm{mg} / \mathrm{kg}$ & GPx, MDA & $\begin{array}{l}\text { Alzheimer's } \\
\text { disease }\end{array}$ & [23] \\
\hline HT22 cells & Neuroprotective & $1.25-5 \mu \mathrm{M}$ & $\begin{array}{l}\text { HO-1, Nrf2, Bcl-2, Bax, AIF, Cyto-c, } \\
\text { p-Akt and p-GSK-3 } \beta\end{array}$ & $\begin{array}{l}\text { Alzheimer's } \\
\text { disease }\end{array}$ & [24] \\
\hline Wistar rat & Neuroprotective & $\begin{array}{l}10 \mu \mathrm{L} \text { of } \\
0.2 \mathrm{mM}\end{array}$ & Bax, Bcl-2, cleaved-caspase-3 & $\begin{array}{l}\text { Spinal cord } \\
\text { injury }\end{array}$ & [25] \\
\hline $\begin{array}{l}\text { Human cell line } \\
\text { SH-SY5Y }\end{array}$ & Antiapoptotic & $1-20 \mu \mathrm{M}$ & 6-OHDA & $\begin{array}{l}\text { Parkinson's } \\
\text { disease }\end{array}$ & [15] \\
\hline Balb/C mice & Antiapoptotic & $\begin{array}{l}20 \text { and } \\
40 \mathrm{mg} / \mathrm{kg}\end{array}$ & TNF- $\alpha$, Bcl-2 & $\begin{array}{l}\text { Autoimmune } \\
\text { hepatitis }\end{array}$ & [17] \\
\hline Neural progenitor cells & Proproliferative & $\begin{array}{l}1,5 \text {, and } \\
10 \mathrm{ng} / \mathrm{mL}\end{array}$ & PI3K, MEK & $\begin{array}{l}\text { Alzheimer's } \\
\text { disease }\end{array}$ & [34] \\
\hline H9c2 rat myocardial cells & Cardioprotective & $0.5-8 \mu \mathrm{M}$ & Bcl-2 & $\begin{array}{l}\text { Cardiovascular } \\
\text { diseases }\end{array}$ & [29] \\
\hline Mouse & Cardioprotective & $5 \mathrm{mg} / \mathrm{kg} / \mathrm{d}$ & GSH-Rs and MDA & $\begin{array}{l}\text { Cardiovascular } \\
\text { diseases }\end{array}$ & [29] \\
\hline Albino Wistar rat & Hepatoprotective & $\begin{array}{c}100 \text { and } \\
250 \mu \mathrm{g} / \mathrm{kg}\end{array}$ & SGPT, SGOT, ALP & $\begin{array}{l}\text { No specific } \\
\text { disease }\end{array}$ & [35] \\
\hline
\end{tabular}

Note: SD: Sprague-Dawley; Nrf2/ARE: nuclear factor-erythroid 2-related factor 2/antioxidant response element; HO-1: heme oxygenase-1; BALF: bronchoalveolar lavage fluid; p38 MAPK: p38mitogen-activated protein kinase; NF- $\kappa$ B-p65: nuclear factor-kappa B-p65; PSD-95: postsynaptic density protein 95; IL-6: interleukin-6; TNF- $\alpha$ : tumor necrosis factor; MDA: malondialdehyde; SOD: superoxide dismutase; GSH: glutathione; CAT: catalase; IFN- $\gamma$ : interferon gamma; IL-2: interleukin 2; IL-10: interleukin 10; IL-1 $\beta$ : interleukin 1 beta; ERK-2: extracellular signal-regulated kinase-2; COX-2: cyclooxygenase-2; MMPs2/9: matrixmetallo proteinases; Akt: protein kinase B; Rad51: Rad51 genes; Con A: concanavalin A; LPS: lipopolysaccharide; CTB: cholera toxin subunit B; Lyn: tyrosine kinase Lyn; ARC: acrosome-reacted cells; GPx: glutathione peroxidase enzyme; MDA: malondialdehyde; AIF: apoptosis-inducing factor; Cyto-c: cytochrome-c; GSK-3 $\beta$ : glycogen synthase kinase-3 $\beta$; Bax: Bcl-2 associated X protein; Bcl-2: B-cell lymphoma 2; GSH-Rs: reduced glutathione; SGPT: serum glutamate transaminase; SGOT: serum glutamate oxaloacetate; ALP: alkaline phosphatase.

most astaxanthin is present as all-trans astaxanthin (97\%), followed by 9 -cis $(0.4 \%), 13$-cis $(1.5 \%)$, and other isomers (1.1\%) [95, 96]. Further, 15-cis and di-cis isomers were identified in addition to all-trans, 13-cis, and 9-cis isomers, in various wild and cultured shrimps in China, Trachysa- lambria curvirostris, Penaeus monodon, Fenneropenaeus chinensis, Litopenaeus vannamei, and Exopalaemon carinicauda [97, 98].

The isomerization of trans-astaxanthin to cis-isomers has been investigated in various organic solvents [99]. All-trans 
TABLE 2: Natural sources of astaxanthin.

\begin{tabular}{|c|c|c|c|c|}
\hline Source & Example of species & $\begin{array}{l}\text { Astaxanthin concentration } \\
\qquad\left(\mathrm{mg} \mathrm{kg}^{-1}\right)^{*}\end{array}$ & Primary optical isomer & Reference \\
\hline \multicolumn{5}{|l|}{ Microorganism } \\
\hline \multirow{11}{*}{ Phytoplankton } & Haematococcus pluvialis NIES-144 & 98,000 d.w. & $3 S, 3^{\prime} S$ & {$[48]$} \\
\hline & Haemotococcus lacustris & 43,100 d.w. & $3 S, 3^{\prime} S$ & {$[49]$} \\
\hline & Haematococcus pluvialis CCAP-34/7 & 22,700 d.w. & $3 S, 3^{\prime} S$ & {$[50]$} \\
\hline & Neochloris wimmeri CCAP-213/4 & 19,200 d.w. & - & {$[50]$} \\
\hline & Protosiphon botryoides SAG-731/1a & 14,300 d.w. & - & {$[50]$} \\
\hline & Scotiellopsis oocystiformis SAG-277/1 & 10,900 d.w. & - & {$[50]$} \\
\hline & Chlorella zofingiensis SAG-211/14 & 6800 d.w. & - & {$[50]$} \\
\hline & Scenedesmus vacuolatus SAG-211/15 & 2700 d.w. & - & {$[50]$} \\
\hline & Chlorococcum sp. & 4230 d.w. & - & {$[51]$} \\
\hline & Chromochloris zofingiensis & 13,100 d.w. & - & {$[52]$} \\
\hline & Euglena sanguinea & - & $3 S, 3^{\prime} S$ & {$[53]$} \\
\hline \multirow{12}{*}{ Zooplankton } & Calanus helgolandicus & $50-220$ d.w. & - & {$[54]$} \\
\hline & Acartia bifilosa & 477.4 d.w. & - & {$[55]$} \\
\hline & Calanus finmarchicus & $100-500$ d.w. & $3 S, 3^{\prime} S$ & {$[56,57]$} \\
\hline & Calanus glacialis & $100-500$ d.w. & - & [56] \\
\hline & Calanus hyperboreus & $100-500$ d.w. & - & {$[56]$} \\
\hline & Calanus pacificus & - & - & {$[58]$} \\
\hline & Diaptomus nevadensis & - & - & {$[58]$} \\
\hline & Neocalanus tonsus & - & - & {$[58]$} \\
\hline & Amphiascoides atopus & 619 d.w. & - & [59] \\
\hline & Acartia bifilosa & $293-487$ d.w. & - & {$[60]$} \\
\hline & Pseudocalanus acuspes & 239-305 d.w. & - & {$[60]$} \\
\hline & Idotea metallica & - & - & {$[61]$} \\
\hline \multirow{10}{*}{ Bacteria } & Agrobacterium aurantiacum & 140 d.w. & $3 S, 3^{\prime} S$ & {$[62]$} \\
\hline & Brevundimonas sp. strain N-5 & 837 d.w. & $3 S, 3^{\prime} S$ & {$[63]$} \\
\hline & Sphingomicrobium astaxanthinifaciens & 40 d.w. & - & {$[64]$} \\
\hline & Paracoccus bogoriensis & 400 w.w. & - & {$[65]$} \\
\hline & Brevundimonas spp. & $27.6-365$ d.w. & $3 S, 3^{\prime} S$ & {$[66]$} \\
\hline & Brevundimonas sp. M7 & 1300 d.w. & $3 S, 3^{\prime} S$ & {$[66]$} \\
\hline & Sphingomonas astaxanthinifaciens & 690 d.w. & - & {$[66]$} \\
\hline & Altererythrobacter ishigakiensis & - & - & {$[67]$} \\
\hline & Paracoccus haeundaensis & - & - & {$[68]$} \\
\hline & Paracoccus carotinifaciens & - & $3 S, 3^{\prime} S$ & {$[69]$} \\
\hline \multirow{3}{*}{ Yeast } & Phaffia rhodozyma PR 190 & 970 d.w. & $3 R, 3^{\prime} R$ & {$[70]$} \\
\hline & Phaffia rhodozyma UCD 67-210 & 387 d.w. & $3 R, 3^{\prime} R$ & {$[71]$} \\
\hline & Candida utilis & 400 d.w. & - & {$[72]$} \\
\hline \multirow{2}{*}{ Archaea } & Halobacterium salinarium NRC-1 & 265 d.w. & - & {$[73]$} \\
\hline & Haloarcula hispanica ATCC 33960 & 17 d.w. & - & {$[73]$} \\
\hline Chromista & Thraustochytrium sp. CHN-3 & 2800 d.w. & - & {$[74]$} \\
\hline \multicolumn{5}{|l|}{ Crustaceans } \\
\hline \multirow{4}{*}{ Shrimp } & Marsupenaeus japonicus & 418 d.w. & - & {$[75]$} \\
\hline & Litopenaeus setiferus & $48.3 w . w$. & - & {$[76]$} \\
\hline & Penaeus sp. & $0.96 w . w$. (only head) & - & {$[77]$} \\
\hline & Litopenaeus vannamei & $11.3-31.8 w . w$ & $3 R, 3^{\prime} S$ & {$[57,78]$} \\
\hline
\end{tabular}


TABLE 2: Continued.

\begin{tabular}{|c|c|c|c|c|}
\hline Source & Example of species & $\begin{array}{l}\text { Astaxanthin concentration } \\
\qquad\left(\mathrm{mg} \mathrm{kg}^{-1}\right)^{*}\end{array}$ & Primary optical isomer & Reference \\
\hline & Penaeus monodon & $24.9-67.5$ d.w. & $3 R, 3^{\prime} \mathrm{S}$ & {$[57,79]$} \\
\hline & Pandalus borealis & $30.9-147.7$ w.w. & $3 R, 3^{\prime} S$ & {$[57,80,81]$} \\
\hline \multirow[t]{2}{*}{ Crawfish } & Procambarus clarkii & 78.5-197.9 d.w. (only shell) & - & {$[82]$} \\
\hline & Pleuroncodes planipes & - & - & {$[83]$} \\
\hline \multirow[t]{2}{*}{ Crabs } & Eriocheir sinensis & $3.5-4.7$ d.w. (only carapace) & - & {$[84]$} \\
\hline & Chionoecetes opilio & 119.6 d.w. & - & {$[81]$} \\
\hline Lobster & Jasus lalandii & $13 w . w$. & - & [85] \\
\hline Antarctic krill & Euphausia superba & - & $3 R, 3^{\prime} R$ & {$[80]$} \\
\hline \multicolumn{5}{|l|}{ Fishes } \\
\hline \multirow{9}{*}{ Salmonids } & Atlantic salmon (Salmo salar) & $6-8 w \cdot w$ & $3 S, 3^{\prime} S$ & {$[3]$} \\
\hline & Sockeye salmon (Oncorhynchus nerka) & $26-38 w . w$. & $3 S, 3^{\prime} S$ & {$[86]$} \\
\hline & Chinook salmon (Oncorhynchus tshawytscha) & $5.4 w . w$. & $3 S, 3^{\prime} S$ & {$[86]$} \\
\hline & Chum salmon (Oncorhynchus keta) & $3-5 w . w$. & $3 S, 3^{\prime} S$ & {$[86]$} \\
\hline & Coho salmon (Oncorhynchus kisutch) & $10-21 w . w$. & $3 S, 3^{\prime} S$ & {$[86]$} \\
\hline & Masu salmon (Oncorhynchus masou) & 4.6 w.w. & $3 S, 3^{\prime} S$ & {$[86]$} \\
\hline & Pink salmon (Oncorhynchus gorbuscha) & $4-7 w . w$ & $3 S, 3^{\prime} S$ & {$[86]$} \\
\hline & Rainbow trout (Oncorhynchus mykiss) & $24 w . w$. & $3 S, 3^{\prime} S$ & {$[86]$} \\
\hline & Arctic char (Salvelinus alpinus) & $8.6 w \cdot w$ & - & [86] \\
\hline
\end{tabular}

* d.w., dry weight; $w . w$., wet weight.

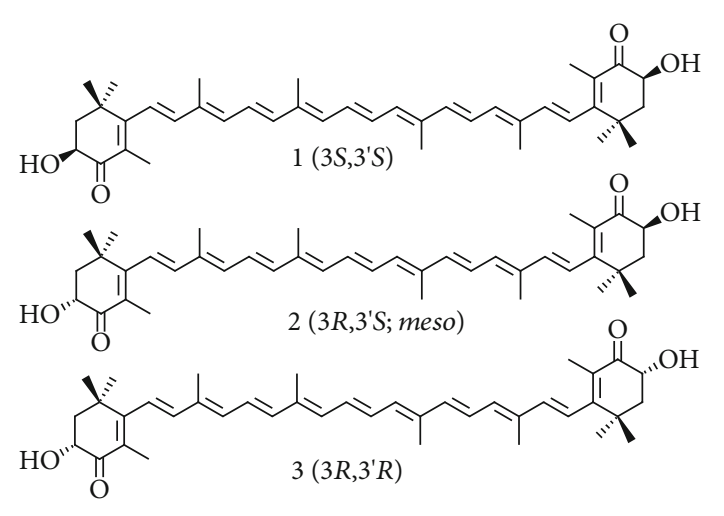

Figure 1: Structures of the optical isomers all-E-(3S, $\left.3^{\prime} S\right)(1)$, all-E$\left(3 R, 3^{\prime} S\right.$; meso $)(2)$, and all-E- $\left(3 R, 3^{\prime} R\right)(3)$ astaxanthin.

natural astaxanthin is readily isomerized to cis-trans mixtures, especially the 9-cis and 13-cis isomers. Increased temperature, exposure to light, or the presence of acids can result in the formation of cis-isomer $[99,100]$. Isomerization of all-trans astaxanthin is challenging because of low stereochemical stability, as well as other factors, such as microwave radiation, ultrasonic vibration, organic solvents, presence of fatty acids, and $\mathrm{Cu}$ (II) ion, which affect the formation yield of different astaxanthin isomers [99-103]. Therefore, isomerization of trans-astaxanthin and cis-isomers has to be minimized during the preparation of pure isomeric forms, i.e., during pigment extraction, astaxanthin ester saponification, and isomer purification. Reversed-phase HPLC can be used to separate the trans and cis-isomers of astaxanthin [100].

3.2. Structure of Astaxanthin Aggregates. Biomolecular aggregation is important in medical treatments. Like many other carotenoids, astaxanthin is expected to self-assemble in hydrated polar solvents to form aggregates [104]. Water concentration in these mixtures impacts the aggregate morphology and greatly affects their photophysical properties. Based on the spectroscopic analysis, the aggregate absorption spectra are blue-shifted or red-shifted compared with those of monomers, depending on the aggregation conditions [105-107]. Specifically, the red-shift is attributed to the formation of $J$-aggregate and the blue-shift is attributed to the formation of $H$-aggregate. J-aggregate consists of astaxanthin molecules arranged head-to-tail and forming a relatively loosely packed aggregate, while $H$-aggregate is characterized by tight "card-pack" stacking where the polyene chains are more or less parallel to each other [108].

Aggregation of astaxanthin in ethanol-water solution has been studied by ultraviolet/visible and fluorescence spectrometry. After the addition of water, astaxanthin immediately forms tightly packed stacks of individual molecules, with a maximum blue shift of $31 \mathrm{~nm}$; the $J$-aggregate forms in $1: 3(v / v)$ ethanol-water solution after an hour [107]. In the case of dimethyl sulfoxide (DMSO), an organic solvent that is usually used for delivering carotenoid in cell culture, the addition of water for a ratio of $1: 1(v / v)$, generates a 
<smiles>C/C=C/C=C(C)/C=C/C=C/C=C(C)/C=C/C=C(C)/C=C/C1=C(C)C(=O)C(O)CC1(C)C</smiles><smiles>CCC(C)=CC=CC=C(C)C=CC=C(C)C=CC1=C(C)C(=O)C(O)CC1(C)C</smiles>
(13-cis)
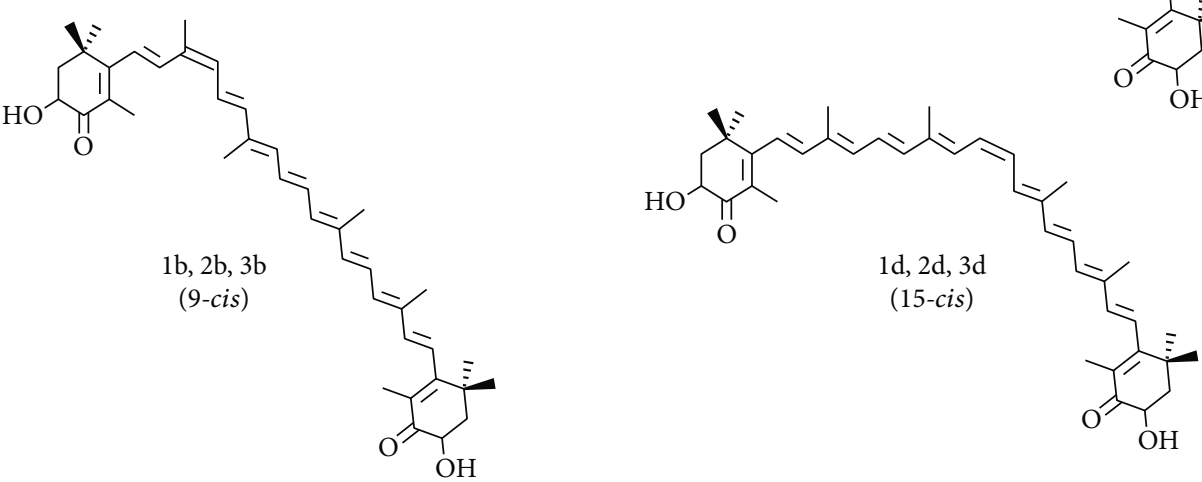

Figure 2: Structure of all-trans (1a, 2a, 3a), 9-cis (1a, 2b, 3c), 13-cis (1c, 2c, 3c), and 15-cis-astaxanthin (1d, 2d, 3d). Note: 1, 3S,3' S; 2, 3R, $3^{\prime} S$; meso; $3,3 R, 3^{\prime} R$.

red-shifted $J$-aggregate with a maximum absorption band at $570 \mathrm{~nm}$. On the other hand, the DMSO/water ratio of $1: 9$ $(v / v)$ produces blue-shifted $H$-aggregate with maximum absorption bands at $386 \mathrm{~nm}$ and $460 \mathrm{~nm}$ [105]. Of note, the formation of astaxanthin aggregates also changes the excited-state dynamic of the compound, i.e., in DMSO/water solution, it results in a longer $S_{1}$ lifetime than that of the corresponding monomer, with the astaxanthin triplet generated exclusively in the astaxanthin aggregate [105]. In nature, astaxanthin also forms monoesters and diesters with fatty acids. Ester formation completely prevents aggregation [109].

3.3. Structure and Bioavailability. As mentioned above, bioavailability of astaxanthin in aquatic animals has been well researched. The all-trans isomer is predominantly found in most body parts of the aquatic animals, including fish and crustaceans. The 13-cis isomer is present in the fish liver at relatively high amounts $[95,96]$. In other words, the configuration of the astaxanthin molecule may influence its absorption, as reported for rainbow trout fed cold-pelleted diets containing select astaxanthin isomers [96]. This resulted in the formulation of the following hypotheses [57]: (1) an isomer that is easily ingested and absorbed accumulates faster than other isomers in an aquatic animal; (2) the isomer is selectively transported in the plasma and between tissues or organs; and (3) astaxanthin may undergo metabolic conversion before deposition in the animal. The higher absorption of all-trans astaxanthin than that of the cis-isomer may be explained by the relatively lower ability of the sterically bulkier cis-isomer to permeate the lipid membrane [110].

Bioavailability of natural astaxanthin stereoisomers from wild and farmed salmon in healthy men was assessed in a randomized and double-blind trial involving 28 volunteers [111]. The participants were given $250 \mathrm{~g}$ of wild or aquacul- ture salmon $\left(5 \mu \mathrm{gg}^{-1}\right)$ daily, for 4 weeks. The plasma astaxanthin concentration and isomer distribution were monitored by HPLC. On day 28 , the $3 S, 3^{\prime} S$ isomer was predominant in the plasma $(80 \%)$ of individuals in the wild salmon intake group, whereas the meso form $\left(3 R, 3^{\prime} S\right)$ was prevalent $(48 \%)$ in the farmed salmon intake group. Although the all-trans astaxanthin has been the subject of many studies, according to recent research, the 9-cis and 13-cis isomers are selectively absorbed by human plasma. Bioavailability of synthetic astaxanthin was also assessed in the plasma and lipoprotein fractions in three middle-aged male volunteers after ingestion of a single meal containing a $100 \mathrm{mg}$ dose of astaxanthin mixture of all-trans (74\%), 9-cis (9\%), and 13-cis isomers (17\%) [110]. Astaxanthin was present mainly in very low-density lipoproteins containing chylomicrons (VLDL/CM; 36-64\%), whereas low-density lipoprotein (LDL) and high-density lipoprotein (HDL) contained $29 \%$ and $24 \%$ of total astaxanthin, respectively. The astaxanthin isomers in HDL, LDL, and VLDL/CM ranged from $62.1-66.9 \%$ for all-trans isomer, $13.2-14.5 \%$ for 9 -cis isomer, and $20.4-24.3 \%$ for 13 -cis isomer, respectively.

Recently, bioaccessibility and bioavailability of all-trans, 9-cis, and 13-cis astaxanthins was investigated using an in vitro digestion model and human intestinal Caco- 2 cells [112]. Indeed, the 13-cis astaxanthin was more bioaccessible than the 9-cis and all-trans forms during in vitro digestion, and 9-cis astaxanthin was transported in human intestinal Caco- 2 cells more efficiently than the all-trans and 13-cis isomers [112]. In terms of absorption efficiency of all isomers during transport across differentiated Caco-2 cell monolayers, cellular uptake was pronounced after $3 \mathrm{~h}$, and the absorption efficiency increased drastically after $12 \mathrm{~h}$ and continued to increase until the $24 \mathrm{~h}$ time point. The absorption efficiency of all-trans isomer was the highest, followed 
by those of 9-cis and 13-cis isomers, indicating that the linear structure of the isomer initially facilitates its permeation of the cell membrane, as compared with the sterically bulky cis-isomers. In the experiment, cis-astaxanthin was more readily isomerized to all-trans isomer than to another cis-isomer, although all-trans astaxanthin tended to be isomerized to 13-cis astaxanthin slightly more readily than to 9-cis astaxanthin [112]. In the experiment, DMSO was used to deliver astaxanthin to the cultured cells. The observations highlight the possible effect of structure on the biological role of these isomers, especially in cellular uptake and transport.

\section{Interaction of Astaxanthin with Reactive Species}

Harmful effects of reactive species are well established. As determined in studies involving animal models and human subjects, reactive species participate in the pathogenesis of acute and chronic diseases. That is because nucleic acids (RNA and DNA), and proteins are the main targets of free radicals $[113,114]$.

Inflammation widely contributes to multiple chronic diseases and is closely linked with oxidative stress. For example, elevated levels of prooxidants and various markers of oxidative stress, and cell and tissue damage are linked to the pathogenesis of cancer, cardiovascular disease, neurodegenerative diseases, reproductive system diseases, and aging [115]. Accumulation of an antioxidant in a cell can reduce or prevent oxidation of oxidizable substrates. An ideal antioxidant should be readily absorbed, eliminate free radicals, and chelate redox metals at physiologically relevant levels [116].

Free radicals contain one or more unpaired electrons. This feature makes them particularly reactive and is also responsible for their ability to trigger chain reactions, propagating the associated molecular damage. Most free radicals are, or arise from, reactive oxygen species (ROS), reactive nitrogen species (RNS), and reactive sulfur species (RSS). ROS include oxygen-based free radicals, i.e., the superoxide radical anion $\left(\mathrm{O}_{2}{ }^{--}\right)$, and hydroxyl $\left(\mathrm{HO}^{\bullet}\right)$, alkoxyl $\left(\mathrm{RO}^{\bullet}\right)$, organic peroxyl $\left(\mathrm{ROO}^{\circ}\right)$, and hydroperoxyl $\left(\mathrm{HOO}^{\circ}\right)$ radicals. RNS comprise peroxynitrite $\left(\mathrm{ONOO}^{-}\right)$, nitric oxide $\left(\mathrm{NO}^{\bullet}\right)$, and nitrogen dioxide $\left(\mathrm{NO}_{2}^{\circ}\right)$. The most common RSS are thiyl radicals $\left(\mathrm{RS}^{\bullet}\right)$, sulfenic acids $(\mathrm{RSOH})$, and disulfide-Soxides $\left[\mathrm{RS}(\mathrm{O})_{2} \mathrm{SR}\right]$. Concerning reactivity, $\mathrm{HO}^{\bullet}$ is the most reactive and dangerous species among $\mathrm{ROS}$. $\mathrm{ROO}^{\bullet}$ is significantly less reactive than $\mathrm{HO}^{\bullet}$, which allows them to diffuse to remote cellular locations [117]. For RNS, the chemical reactivity of $\mathrm{NO}^{\bullet}$ is low, but it reacts with $\mathrm{O}_{2}{ }^{--}$yielding peroxynitrite, a highly damaging species, to react with lipids, protein, and DNA [117].

Since RNS and RSS are less reactive than the reactive oxygen species, below, we focus on ROS.

4.1. Generation of ROS. In the cell, ROS are produced by enzymes of different origin, mainly by the cytoplasmic membrane NADPH oxidase; the enzyme complex of the mitochondrial respiratory chain; and such enzymes as xanthine oxidase, lipo- and cyclooxygenase, and cytochromes P450 in the endoplasmic reticulum, peroxisomes, and others
[43]. The mitochondrial respiratory chain is a main contributor, as $85 \%$ of oxygen metabolized the mitochondrion and partially reduced oxygen intermediates are produced therein [118]. In this organelle, $\mathrm{O}_{2}{ }^{--}$and $\mathrm{H}_{2} \mathrm{O}_{2}$ participate in redox signaling [119], but their production is greatly enhanced during oxidative stress, for example in response to various diseases or stimuli.

Oxidative stress reflects an imbalance between the production of ROS and the action of the antioxidant defense system in charge of their neutralization. The defense system includes superoxide dismutase, which reduces $\mathrm{O}_{2}{ }^{--}$to $\mathrm{H}_{2} \mathrm{O}_{2}$ [120], and catalase, glutathione peroxidase, and thioredoxin reductase, which regulate $\mathrm{H}_{2} \mathrm{O}_{2}$ levels by converting it to $\mathrm{H}_{2} \mathrm{O}$ and $\mathrm{O}_{2}[121,122]$. The production of $\mathrm{HO}^{\bullet}$ was usually obtained by Fenton reaction, with $\mathrm{Fe}^{2+}$ reducing $\mathrm{H}_{2} \mathrm{O}_{2}$ to $\mathrm{HO}^{\bullet}$ and $\mathrm{HO}^{-}$(Figure 3). In this case, ROS are generated by a metal-catalyzed reaction and the resulting oxidative damage is often site-directed, particularly when the biomolecules coordinate metal ions [123].

In a biological context, the toxicity of $\mathrm{O}_{2}{ }^{\bullet-}$ is indirect since the species is involved in the generation of highly reactive secondary species $\left(\mathrm{HO}^{\bullet}\right)$ [124]. The latter is generated by the reaction of superoxide $\left(\mathrm{O}_{2}{ }^{--}\right)$and hydrogen peroxide $\left(\mathrm{H}_{2} \mathrm{O}_{2}\right)$ (the Haber-Weiss reaction) (Figure 3). The reaction is thermodynamically, but not kinetically, favorable, and has to be catalyzed by a metal ion, for example, ferrous iron [125].

Further, $\mathrm{H}_{2} \mathrm{O}$ as an oxidant is not thermodynamically favorable under biological conditions $\left[\mathrm{E}^{\circ}\left(\mathrm{O}_{2}{ }^{\bullet-} / \mathrm{H}_{2} \mathrm{O}_{2}\right)=0.93 \mathrm{~V}\right.$ and $\mathrm{E}^{\circ}\left(\mathrm{H}_{2} \mathrm{O}_{2} / \mathrm{HO}^{\bullet}\right)=0.30 \mathrm{~V}$ ] [126]. The highest oxidizing potential of this molecule is achieved indirectly, when it is converted into $\mathrm{HO}^{\bullet}$ radicals via the metal-catalyzed Fenton and Haber-Weiss reactions (Figure 3 ).

The hydroxyl radical is a powerful oxidant among ROS, with a potential of $\mathrm{E}^{\circ}\left(\mathrm{HO}^{\bullet} / \mathrm{H}_{2} \mathrm{O}\right)=2.34 \mathrm{~V}$ [126]. It can be converted to a relatively less reactive oxide radical, $\mathrm{O}^{\bullet-}$, at very low $\mathrm{pH}\left[\mathrm{pK}_{\mathrm{a}}\left(\mathrm{HO}^{\bullet} / \mathrm{O}^{\bullet-}\right)=11.9\right]$ [127]; however, this conversion is not relevant at physiological $\mathrm{pH}$.

The $\mathrm{HO}^{\bullet}$ radical is electrophilic and has a strong affinity for electron-rich sites of molecules [127]. The radical targets numerous and various biomolecules via $\mathrm{H}$-abstraction, leading to the formation of carbon-centered radicals that rapidly react with molecular oxygen to generate the peroxyl radical $\left(\mathrm{ROO}^{\circ}\right)$. The latter reacts faster than the superoxide anion with numerous biological substrates (DNA, lipids, and proteins) with the rate constant ranging from $10^{2}$ to $10^{8} \mathrm{~L} \mathrm{~mol}^{-1} \mathrm{~s}^{-1}[128]$.

4.2. Astaxanthin Structure and Antioxidant Activity. A qualified antioxidant should be involved in one or more of the following processes to protect a biological system against oxidative damage [2]: (i) oxygen depletion; (ii) quenching of singlet oxygen molecules; (iii) scavenging of ROS or termination of a chain reaction of oxidation propagation; (iv) chelation of metal ion that otherwise could catalyze ROS formation; or (v) repair of oxidative damage. A range of ROS is found in the human body. Accordingly, the essential role of astaxanthin as an antioxidant is to deactivate reactive oxidants, such as singlet oxygen and ROS (processes $1-3)$, in particular, peroxyl radical intermediates $[47,80,129]$. 


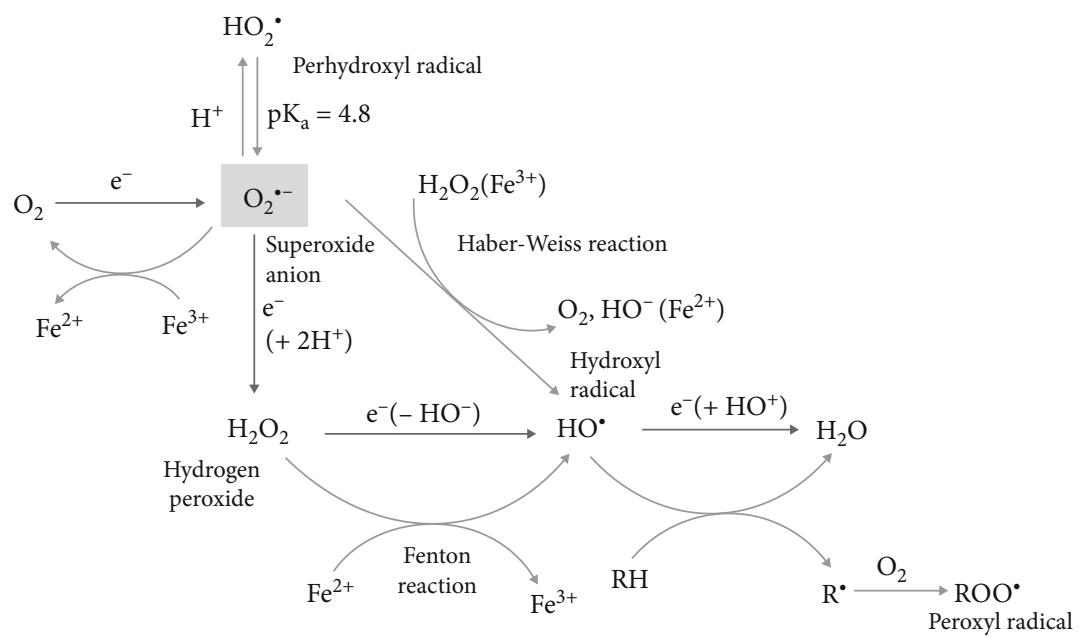

Figure 3: Chemical players in the generation of reactive oxygen species (ROS): superoxide anion $\left(\mathrm{O}_{2}{ }^{\bullet-}\right)$ radical, perhydroxyl $\left(\mathrm{HO}_{2}{ }^{\bullet}\right)$ radical, metal-catalyzed conversion of superoxide anion $\left(\mathrm{O}_{2}{ }^{--}\right)$and hydrogen peroxide $\left(\mathrm{H}_{2} \mathrm{O}_{2}\right)$ into hydroxyl $\left(\mathrm{HO} \mathrm{O}^{\bullet}\right.$ radical, and peroxyl radical $\left(\mathrm{ROO}^{\circ}\right)$.

The scavenging reaction not only depends on the carotenoid structure but also on the properties of free radicals [130]. Indeed, certain radicals elicit electron transfer, while others only engage in an addition reaction [131]. The environment plays an important role as well, with the solvent polarity leading to different mechanisms of radical-carotenoid interactions [131]. In general, three possible mechanisms of carotenoid (Car in the equations below) interactions with ROS exist: (i) hydrogen abstraction or hydrogen atom transfer from the side chain, i.e., C4-position of the cyclohexene ring (Equation (1)); (ii) radical addition to the polyene chain (Equation (2)); and (iii) electron transfer yielding a carotenoid radical cation (Equation (3)) [132, 133].

$$
\begin{gathered}
\mathrm{ROO}^{\bullet}+\mathrm{Car} \rightarrow \mathrm{ROOH}+\mathrm{Car}^{\bullet}, \\
\mathrm{ROO}^{\bullet} \mathrm{V}+\mathrm{Car} \rightarrow(\mathrm{ROO}-\mathrm{Car})^{\bullet}, \\
\mathrm{ROO}^{\bullet}+\mathrm{Car} \rightarrow \mathrm{ROO}^{-}+\mathrm{Car}^{\bullet+}, \\
{ }^{1} \mathrm{O}_{2} *+\mathrm{Car} \rightarrow{ }^{3} \mathrm{O}_{2}+{ }^{3} \mathrm{Car} *
\end{gathered}
$$

Many well-documented examples of reaction mechanisms corresponding to the reactions described by Equations (2) and (3) are known; however, the majority concern $\beta$-carotene [132-135]. Astaxanthin is a carotenoid with the best scavenging capacity for peroxyl and hydroxyl radicals [136, 137]. The $\mathrm{HO}^{\bullet}$ scavenging capacity of astaxanthin is $66 \%$ and $17 \%$ greater than that of Trolox and quercetin, respectively, and only $6 \%$ less potent than that of $\alpha$-tocopherol [136]. However, with respect to ROO', astaxanthin is $16 \%$ more potent than $\alpha$-tocopherol [136]. Hypothetically, the keto group potentially activates the hydroxyl group, resulting in the formation of an ortho-dihydroxy-conjugate polyene system that facilitates hydrogen transfer (Equation (1)) to the peroxyl radical, in a manner similar to that of the hydroxyl group of $\alpha$-tocopherol [138]. As determined in an electrochemical study of carotenoid in solution using cyclic voltammetry, upon electron transfer from the carotenoid molecule, the radical cation $\mathrm{Car}^{\bullet+}$ is formed at an oxidation potential $\mathrm{E}_{1}^{\circ}$. The second lost electron forms the dication $\mathrm{Car}^{2+}$ at an oxidation potential $\mathrm{E}_{2}^{\circ}$. The electrochemical measurement of astaxanthin, and astaxanthin monoester and diester, indicated that astaxanthin $\left[\mathrm{E}_{1}{ }^{\circ}\left(\mathrm{Car} / \mathrm{Car}^{\circ+}\right)=\right.$ $0.768 \mathrm{~V}]$ has a higher oxidation potential than other carotenoids, such as $\beta$-carotene $\left[\mathrm{E}_{1}{ }^{\circ}\left(\mathrm{Car} / \mathrm{Car}^{\circ+}\right)=0.634 \mathrm{~V}\right]$, zeaxanthin $\left[\mathrm{E}_{1}{ }^{\circ}\left(\mathrm{Car} / \mathrm{Car}^{\bullet+}\right)=0.63 \mathrm{~V}\right]$, and lycopene $\left[\mathrm{E}_{1}{ }^{\circ}\left(\mathrm{Car} / \mathrm{Car}^{\bullet+}\right)\right.$ $=0.60 \mathrm{~V}][135,139]$. Furthermore, electrochemical in combination with electron paramagnetic resonance (EPR) spin trapping studies demonstrated that with an increasing first oxidation potential of the carotenoid molecule, the relative scavenging ability also increases, towards peroxyl radicals $\mathrm{HOO}^{\bullet}$ formed in a Fenton reaction via the reaction between $\mathrm{H}_{2} \mathrm{O}_{2}$ and $\mathrm{HO}^{\circ}$ $[139,140]$. The antioxidative effects of astaxanthin were evaluated in 35 individuals who underwent bilateral cataract surgery by monitoring the changes in superoxide scavenging activity, and hydrogen peroxide and total hydroperoxide levels in human aqueous humor [141]. After astaxanthin intake, the superoxide scavenging activity was greatly elevated, while the total hydroperoxide levels were significantly lowered [141].

Based on in vitro studies, astaxanthin esters act as powerful quenchers of singlet oxygen under both hydrophilic and hydrophobic conditions [142]. Kinetic studies of the quenching reaction of singlet molecular oxygen $\left({ }^{1} \mathrm{O}_{2}\right)$ by carotenoids and food extracts in solution revealed that carotenoids with 11 carbon atoms involved in the $\pi$-conjugation $(n)$, such as astaxanthin, quench ${ }^{1} \mathrm{O}_{2}$ most effectively $[143,144]$. The quenching mechanism was proposed to involve an energy transfer from the singlet oxygen to produce the carotenoid triplet state $\left({ }^{3} \mathrm{Car}\right.$ ) (Equation (4)) because of the two oxo groups in the conjugated astaxanthin system [145-147]. Astaxanthin in the energy-rich triplet state can return to the ground state by dissipating the energy as heat [146]. Recent quantum dynamic calculations and $a b$ initio 
TABLE 3: Second-order quenching rate constants for the quenching of singlet oxygen by astaxanthin.

\begin{tabular}{|c|c|c|c|}
\hline $\begin{array}{l}\text { Quenching rate constant } \\
\left(k_{\mathrm{q}}, 10^{8} \mathrm{M}^{-1} \mathrm{~s}^{-1}\right)\end{array}$ & Method & Solvent & Ref. \\
\hline 5.9 & Rose Bengal-sensitized photooxidation & DPP liposomes & [150] \\
\hline 0.19 & Rose Bengal-sensitized photooxidation & $\begin{array}{l}\text { Stearylamine and dimyristoylphosphatidylcholine } \\
\text { liposomes }\end{array}$ & \multirow{2}{*}[151]{} \\
\hline 0.19 & $\begin{array}{l}\text { 12-(1-Pyrene)-dodecanoic acid-sensitized } \\
\text { photooxidation }\end{array}$ & Dimyristoylphosphatidylcholine liposomes & \\
\hline 140 & Phenazine sensitization & Benzene & [152] \\
\hline 71.1 & $\begin{array}{c}\text { Thermal decomposition of 3- } \\
\text { (1,4-epidioxy-4-methyl-1, } \\
\text { 4-dihydro-1-naphthyl) propionic acid as } \\
\text { endoperoxide }\end{array}$ & $\begin{array}{c}\text { Triton X-100 solution } \\
\text { (5 wt\%; } 0.02 \mathrm{M} \text { phosphate buffer, } \mathrm{pH} 7.4)\end{array}$ & [153] \\
\hline 118 & $\begin{array}{c}\text { Thermal decomposition of 3- } \\
\text { (1,4-epidioxy-4-methyl-1, } \\
\text { 4-dihydro-1-naphthyl) propionic acid as } \\
\text { endoperoxide }\end{array}$ & Ethanol:chloroform: $\mathrm{D}_{2} \mathrm{O}(50: 50: 1, v / v / v)$ & [154] \\
\hline 240 & $\begin{array}{l}\text { Thermodissociation of the endoperoxide } \\
\text { of } \mathrm{NDPO}_{2}\end{array}$ & Ethanol/chloroform $/ \mathrm{H}_{2} \mathrm{O}(50: 50: 1, v / v)$ & [155] \\
\hline $\begin{array}{l}22 \\
(18)\end{array}$ & $\begin{array}{l}\text { Thermodissociation of the endoperoxide } 1 \text {, } \\
\text { 4-dimethyl-naphthalene }\end{array}$ & $\begin{array}{c}\mathrm{CDCl} 3 \\
\left(\mathrm{CDCl}_{3} / \mathrm{CD}_{3} \mathrm{OD}(2: 1, v / v)\right)\end{array}$ & {$[156]$} \\
\hline
\end{tabular}

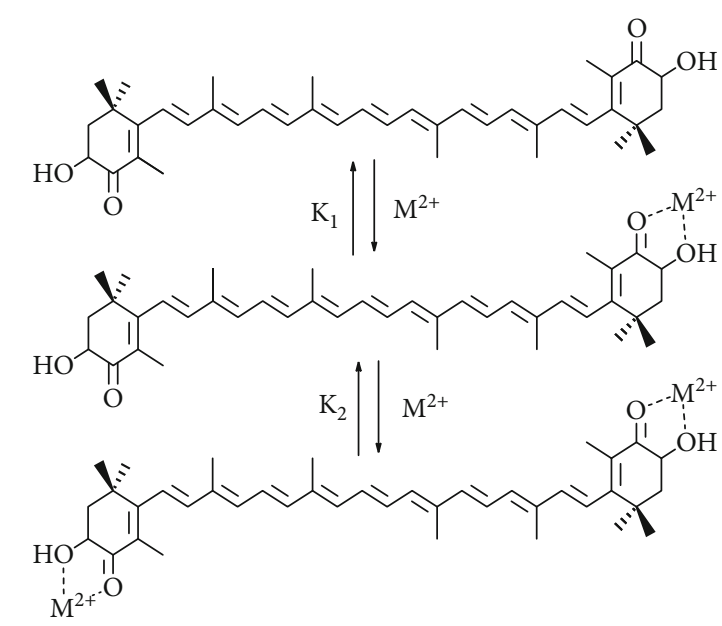

FIGURE 4: Complexation of astaxanthin with metal ions (adaptatrd from [161]).

calculations suggest that once ${ }^{1} \mathrm{O}_{2}$ and carotenoids make a van der Waals contact, the strong electronic coupling induces an ultrafast ${ }^{1} \mathrm{O}_{2}$ quenching, which overcomes the large energy gap to the $\mathrm{Car}^{\bullet+} / \mathrm{O}_{2}{ }^{\bullet-}$ intermediate states [148]. Effects of astaxanthin supplementation on aging have been examined in the model organism Caenorhabditis elegans. Indeed, astaxanthin effectively quenched ${ }^{1} \mathrm{O}_{2}$, thus protecting the mitochondrion and nucleus from oxidative injury and extending the lifespan [149].

The antioxidant capacity of astaxanthin can be determined from the quenching rate constant of singlet oxygen. A fast quenching rate constant indicates efficient singlet oxygen quenching. The quenching rate constants of singlet oxygen for astaxanthin determined by various methods and in various environments are shown in Table 3 . The rate constants of astaxanthin in organic solvents $\left(18-240 \times 10^{8} \mathrm{M}^{-1} \mathrm{~s}^{-1}\right)$ are higher than those in micelle $\left(71.1 \times 10^{8} \mathrm{M}^{-1} \mathrm{~s}^{-1}\right)$ and liposome $\left(0.19-5.9 \times 10^{8} \mathrm{M}^{-1} \mathrm{~s}^{-1}\right)$. The rate constants in heterogeneous environment are lower than those in organic solvents, which can be explained by a slower diffusion of singlet oxygen from the aqueous phase to the micelle or lipid membrane in these environments [150]. In addition, the quenching rate constants of astaxanthin using Rose Bengal- and 12-(1-pyrene)-dodecanoic acid-sensitized photooxidation methods are 100-667-fold (in ethanol) and 1-8-fold (liposomes) higher than those of $\alpha$-tocopherol [151].

The molecular structure of astaxanthin endows it with unique properties. Hydroxyl and keto groups are present at positions $\mathrm{C} 3\left(\mathrm{C}^{\prime}\right)$ and $\mathrm{C} 4\left(\mathrm{C}^{\prime}\right)$, respectively, on each ionone ring. The two adjacent oxygen atoms on the cyclohexene ring enable the formation of stable complexes with metal ions (Figure 4 ), as is also observed in many $\alpha$-hydroxyketones and hydroxyquinones $[157,158]$. The generation of highly reactive oxygen species $\left(\mathrm{HO}^{\bullet}\right)$ via Fenton and photoFenton reactions in vitro can be completely inhibited by the chelation of metal ions $\mathrm{Fe}^{2+}$ or $\mathrm{Cu}^{2+}$ [159]. According to a density functional theory study, astaxanthin may form metal ion complexes with such metal ions as $\mathrm{Ca}^{2+}, \mathrm{Cu}^{2+}, \mathrm{Pb}^{2+}$, $\mathrm{Zn}^{2+}, \mathrm{Cd}^{2+}$, and $\mathrm{Hg}^{2+}[160]$. Indeed, the interaction of astaxanthin with metal ion complexes, i.e., $\mathrm{Ca}^{2+}, \mathrm{Zn}^{2+}$, and $\mathrm{Fe}^{2+}$, was evaluated by mass spectrometry and nuclear magnetic resonance. The analysis revealed that the two oxygen atoms at the terminal cyclohexene rings chelate the metal to form $1: 1$ complexes at low $\mathrm{Ca}\left(\mathrm{ClO}_{4}\right)_{2}, \mathrm{Zn}\left(\mathrm{ClO}_{4}\right)_{2}$, and $\mathrm{Fe}\left(\mathrm{ClO}_{4}\right)_{2}$ salt concentrations; at high salt concentrations $(>0.2 \mathrm{mM})$, a 2:1 salt to astaxanthin complex is formed [161]. Furthermore, the stability constant of $1: 1$ astaxanthin complex with $\mathrm{Fe}\left(\mathrm{ClO}_{4}\right)_{2}$ was calculated to be $\mathrm{K}_{1}=3000 \mathrm{M}^{-1}$, whereas for 
TABLE 4: Antioxidant assays and methods for the determination of antioxidant activity for astaxanthin and its isomers.

\begin{tabular}{|c|c|c|c|c|}
\hline Type & Method & Antioxidant activity & Unit & Reference \\
\hline Astaxanthin & & $17.5 \pm 3.6$ & \multirow{2}{*}{$\mu \mathrm{g} / \mathrm{mL}$} & {$[165]$} \\
\hline Astaxanthin & \multirow{4}{*}{ Free-radical scavenging activity (DPPH) } & $39.1 \pm 1.14$ & & {$[166]$} \\
\hline All-trans & & 5.06 & & \\
\hline 13-cis & & 6.49 & $\mathrm{TE} / \mathrm{mg}$ & \\
\hline 9-cis & & 8.85 & & \\
\hline All-trans & \multirow{4}{*}{$\begin{array}{l}\text { Oxygen radical absorbing capacity for } \\
\text { lipophilic compounds }\end{array}$} & 7.65 & & \\
\hline 13 -cis & & 13.22 & $\mathrm{TE} / \mathrm{mg}$ & {$[164]$} \\
\hline 9-cis & & 11.16 & & \\
\hline All-trans & & 92.22 & & \\
\hline 13 -cis & \multirow[t]{2}{*}{ Photochemiluminescence } & 117.01 & $\mu \mathrm{mol} \mathrm{TE} / \mathrm{g}$ & \\
\hline 9-cis & & 103.41 & & \\
\hline Astaxanthin & Radical scavenging activity (ABTS) & $7.7 \pm 0.6$ & \multirow{3}{*}{$\mathrm{EC} 50, \mu \mathrm{g} / \mathrm{mL}$} & \multirow{3}{*}[165]{} \\
\hline Astaxanthin & $\beta$-Carotene bleaching activity & $15.1 \pm 1.9$ & & \\
\hline Astaxanthin & Singlet oxygen scavenging activity & $9.2 \pm 0.5$ & & \\
\hline Astaxanthin & Ferric reducing antioxidant power & 0.5 & \multirow{3}{*}{$\mathrm{mol} \alpha-\mathrm{TE} / \mathrm{mol}$} & \multirow{3}{*}[167]{} \\
\hline Astaxanthin & ABTS bleaching assay $(\alpha$ TEAC) & 0.8 & & \\
\hline Astaxanthin & $\begin{array}{l}\text { Luminol-chemiluminescence based Peroxyl radical } \\
\text { scavenging capacity (LPSC) }\end{array}$ & 26.3 & & \\
\hline
\end{tabular}

Note: ABTS: 2,2' -azino-bis-3-ethylbenzthiazoline-6-sulphonic acid; DPPH: 2,2-diphenyl-1-picrylhydrazyl; LPSC: luminal-chemiluminescence peroxyl radical scavenging; mol $\alpha$-TE/mol: mol $\alpha$-tocopherol equivalent per mol; TE: Trolox equivalent; $\alpha$ TEAC: $\alpha$-tocopherol equivalent antioxidant capacity.

$1: 1$ complex with $\mathrm{Ca}\left(\mathrm{ClO}_{4}\right)_{2}$, the stability constants are $\mathrm{K}_{1}$ $=23,000 \mathrm{M}^{-1}$ and $\mathrm{K}_{2}=5000 \mathrm{M}^{-1}$. The ability to form chelate complexes with metals could be related to the efficiency with which astaxanthin acts as a protective agent, particularly in inhibiting hydroxyl radicals [135].

The geometrical isomers of astaxanthin play an important role in its antioxidant activity. A microassay evaluating the peroxyl radical scavenging capacity of 15 carotenoid standards has been developed and validated, specifically to study the structure-activity relationship [162]. The values for $\mathrm{ROO}^{\bullet}$ scavenging capacity were then calculated using $\alpha$-tocopherol as a reference compound. Among the carotenoids studied, all-trans astaxanthin was identified as a highly efficient $\mathrm{ROO}^{\bullet}$ scavenger $(6.50 \pm 0.62, \alpha$-tocopherol relative) [162]. As determined by a radical 2,2-diphenyl-1-picrylhydrazyl (DPPH) scavenging activity test and lipid peroxidation test, the cis isomers of astaxanthin, especially the 9-cis isomer, showed a higher antioxidant potential in vitro than all-trans astaxanthin [163]. Furthermore, among all astaxanthin isomers, the 9-cis isomer also most effectively inhibits the generation of ROS induced by 6hydroxydopamine in human neuroblastoma SH-SY5Y cells, as well as the degradation of collagen type II induced by docosahexaenoic acid (DHA) and linoleic acid hydroperoxides [163]. The 13-cis astaxanthin had higher antioxidant activity than all-trans and 9-cis in oxygen radical absorbing capacity assay for lipophilic compounds, photochemiluminescence, and cellular antioxidant activity assay [164]. It was shown that all isomers were relatively stable between $\mathrm{pH} 2.0-11.6$, except for 9-cis and 13-cis astaxanthin at pH2. Different methods of antioxidant evaluation and antioxidant activity of astaxanthin and cis-trans isomers are summarized in Table 4.

\section{Conclusion}

In the last decade, studies on astaxanthin as a potent therapeutic agent have shown encouraging results. Astaxanthin can potentially be used to address various human health issues, including cancer, cardiovascular and neurodegenerative diseases, and aging. These diseases are mostly associated with inflammation caused by an interaction of nucleic acids and proteins with harmful reactive species. These effects are related to the unique properties of astaxanthin molecular structure that allow it to scavenge reactive species and quench singlet oxygen. Recent experiments have uncovered the contribution of different astaxanthin isomers to antioxidant activities, both in vitro and in vivo. However, there is a lack of research on astaxanthin and its metabolism in biological systems. Future research should focus on the physicochemical properties of different astaxanthin structures, their uptake mechanisms, and the facility of incorporation into metabolic pathways. Molecular studies involving in vitro and in vivo models should also be performed to investigate the nutraceutical and pharmaceutical applications of various astaxanthin isomers.

\section{Conflicts of Interest}

The authors declare that there are no conflicts of interest regarding the publication of this paper.

\section{Acknowledgments}

This work was supported by the Ministry of Research and Technology of Indonesia/National Research and Innovation 
Agency through Basic Research Scheme (grant number 9/E1/KPT/2020) and the Fundamental Research Grant (grant number 005/PER-P2M/UPJ-DIKTI/04.19).

\section{References}

[1] H. A. Frank and R. J. Cogdell, "The photochemistry and function of carotenoids in photosynthesis," in Carotenoids in Photosynthesis, A. J. Young and G. Britton, Eds., pp. 252-326, Springer, Dordrecht, 1993.

[2] C. Galasso, C. Corinaldesi, and C. Sansone, "Carotenoids from Marine Organisms: Biological Functions and Industrial Applications," Antioxidants, vol. 6, no. 4, p. 96, 2017.

[3] R. R. Ambati, P. S. Moi, S. Ravi, and R. G. Aswathanarayana, "Astaxanthin: sources, extraction, stability, biological activities and its commercial applications - a review," Marine Drugs, vol. 12, no. 1, pp. 128-152, 2014.

[4] A. McWilliams, FOD025F the Global Market for Carotenoids BCC Research Report Overview the Global Market for Carotenoids, BBC Research, Massachusetts, 2018.

[5] K. Solymosi, N. Latruffe, A. Morant-Manceau, and B. Schoefs, "Food colour additives of natural origin," in Woodhead Publishing Series in Food Science, Technology and Nutrition, M. J. Scotter, Ed., pp. 3-34, Woodhead Publishing, Oxford, 2015.

[6] M. Guerin, M. E. Huntley, and M. Olaizola, “_Haematococcus_ astaxanthin: applications for human health and nutrition," Trends in Biotechnology, vol. 21, no. 5, pp. 210-216, 2003.

[7] X. Xie, Q. Chen, and J. Tao, “Astaxanthin promotes Nrf2/ARE signaling to inhibit hg-induced renal fibrosis in GMCs," Marine Drugs, vol. 16, no. 4, pp. 117-117, 2018.

[8] H. Kubo, K. Asai, K. Kojima et al., “Astaxanthin suppresses cigarette smoke-induced emphysema through Nrf2 activation in mice," Marine Drugs, vol. 17, no. 12, p. 673, 2019.

[9] J. P. Yang, J. H. Shin, S. H. Seo, S. G. Kim, S. H. Lee, and E. H. Shin, "Effects of antioxidants in reducing accumulation of fat in hepatocyte," International Journal of Molecular Sciences, vol. 19, no. 9, article 2563, 2018.

[10] X. Yang, A. L. Guo, Y. P. Pang et al., “Astaxanthin attenuates environmental tobacco smoke-induced cognitive deficits: a critical role of p38 MAPK," Marine Drugs, vol. 17, no. 1, p. 24, 2019.

[11] R. G. Fassett and J. S. Coombes, "Astaxanthin, oxidative stress, inflammation and cardiovascular disease," Future Cardiology, vol. 5, no. 4, pp. 333-342, 2009.

[12] K. Ohgami, K. Shiratori, S. Kotake et al., "Effects of astaxanthin on lipopolysaccharide-induced inflammation in vitro and in vivo," Investigative Ophthalmology and Visual Science, vol. 44, no. 6, pp. 2694-2701, 2003.

[13] Y. Solomonov, N. Hadad, and R. Levy, "The combined antiinflammatory effect of Astaxanthin, Lyc-O-Mato and Carnosic acid in vitro and in vivo in a mouse model of peritonitis," Journal of Nutrition \& Food Sciences, vol. 8, pp. 1-7, 2018.

[14] X. Lin, Y. Zhao, and S. Li, "Astaxanthin attenuates glutamateinduced apoptosis via inhibition of calcium influx and endoplasmic reticulum stress," European Journal of Pharmacology, vol. 806, pp. 43-51, 2017.

[15] Y. Ikeda, S. Tsuji, A. Satoh, M. Ishikura, T. Shirasawa, and T. Shimizu, "Protective effects of astaxanthin on 6hydroxydopamine-induced apoptosis in human neuroblas- toma SH-SY5Y cells," Journal of Neurochemistry, vol. 107, no. 6, pp. 1730-1740, 2008.

[16] H. Q. Wang, X. B. Sun, Y. X. Xu, H. Zhao, Q. Y. Zhu, and C. Q. Zhu, "Astaxanthin upregulates heme oxygenase-1 expression through ERK1/2 pathway and its protective effect against beta-amyloid-induced cytotoxicity in SH-SY5Y cells," Brain Research, vol. 1360, pp. 159-167, 2010.

[17] J. Li, Y. Xia, T. Liu et al., "Protective effects of astaxanthin on conainduced autoimmune hepatitis by the JNK/p-JNK pathway-mediated inhibition of autophagy and apoptosis," PLoS One, vol. 10, no. 3, article e0120440, 2015.

[18] K. H. Lin, K. C. Lin, W. J. Lu, P. A. Thomas, T. Jayakumar, and J. R. Sheu, "Astaxanthin, a carotenoid, stimulates immune responses by enhancing IFN- $\gamma$ and Il-2 secretion in primary cultured lymphocytes in vitro and ex vivo," International Journal of Molecular Sciences, vol. 17, pp. 1-10, 2016.

[19] J. S. Park, J. H. Chyun, Y. K. Kim, L. L. Line, and B. P. Chew, "Astaxanthin decreased oxidative stress and inflammation and enhanced immune response in humans," Nutrition and Metabolism, vol. 7, no. 1, p. 18, 2010.

[20] J. Dhinaut, A. Balourdet, M. Teixeira, M. Chogne, and Y. Moret, "A dietary carotenoid reduces immunopathology and enhances longevity through an immune depressive effect in an insect model," Scientific Reports, vol. 7, no. 1, p. 12429, 2017.

[21] S. Davinelli, H. M. Melvang, L. P. Andersen, G. Scapagnini, and M. E. Nielsen, "Astaxanthin from shrimp cephalothorax stimulates the immune response by enhancing IFN- $\gamma$, IL-10, and IL-2 secretion in splenocytes of helicobacter pyloriinfected mice," Marine Drugs, vol. 17, no. 7, pp. 382-389, 2019.

[22] Y. Nai, H. Liu, X. Bi, H. Gao, and C. Ren, "Protective effect of astaxanthin on acute cerebral infarction in rats," Human \& Experimental Toxicology, vol. 37, no. 9, pp. 929-936, 2017.

[23] T. Taksima, P. Chonpathompikunlert, M. Sroyraya, P. Hutamekalin, M. Limpawattana, and W. Klaypradit, "Effects of astaxanthin from shrimp shell on oxidative stress and behavior in animal model of Alzheimer's disease," Marine Drugs, vol. 17, no. 11, p. 628, 2019.

[24] X. Wen, A. Huang, J. Hu et al., "Neuroprotective effect of astaxanthin against glutamate-induced cytotoxicity in HT22 cells: involvement of the Akt/GSK-3 $\beta$ pathway," Neuroscience, vol. 303, pp. 558-568, 2015.

[25] A. Masoudi, L. Dargahi, F. Abbaszadeh et al., "Neuroprotective effects of astaxanthin in a rat model of spinal cord injury," Behavioural Brain Research, vol. 329, pp. 104-110, 2017.

[26] S. Fakhri, L. Dargahi, F. Abbaszadeh, and M. Jorjani, “Astaxanthin attenuates neuroinflammation contributed to the neuropathic pain and motor dysfunction following compression spinal cord injury," Brain Research Bulletin, vol. 143, pp. 217-224, 2018.

[27] M. Zhang, Z. Cui, H. Cui, Y. Cao, C. Zhong, and Y. Wang, "Astaxanthin alleviates cerebral edema by modulating NKCC1 and AQP4 expression after traumatic brain injury in mice," BMC Neuroscience, vol. 17, no. 1, pp. 60-69, 2016.

[28] X. Ji, D. Peng, Y. Zhang et al., "Astaxanthin improves cognitive performance in mice following mild traumatic brain injury," Brain Research, vol. 1659, pp. 88-95, 2017.

[29] C. D. Fan, J. Y. Sun, X. T. Fu et al., "Astaxanthin attenuates homocysteine-induced cardiotoxicity in vitro and in vivo by 
inhibiting mitochondrial dysfunction and oxidative damage," Frontiers in Physiology, vol. 8, article 1041, 2017.

[30] H. Y. Kim, Y. M. Kim, and S. Hong, “Astaxanthin suppresses the metastasis of colon cancer by inhibiting the MYC- mediated downregulation of microRNA-29a-3p and microRNA200a," Scientific Reports, vol. 9, no. 1, p. 9457, 2019.

[31] P. Nagendraprabhu and G. Sudhandiran, "Astaxanthin inhibits tumor invasion by decreasing extracellular matrix production and induces apoptosis in experimental rat colon carcinogenesis by modulating the expressions of ERK-2, NFkB and COX-2," Investigational New Drugs, vol. 29, no. 2, pp. 207-224, 2011.

[32] J. C. Ko, J. C. Chen, T. J. Wang et al., "Astaxanthin downregulates Rad51 expression via inactivation of AKT kinase to enhance mitomycin C-induced cytotoxicity in human non-small cell lung cancer cells," Biochemical Pharmacology, vol. 105, pp. 91-100, 2016.

[33] G. Donà, A. Andrisani, E. Tibaldi et al., "Astaxanthin prevents human papillomavirus L1 protein binding in human sperm membranes," Marine Drugs, vol. 16, no. 11, p. 427, 2018.

[34] J. H. Kim, S. W. Nam, B. W. Kim et al., "Astaxanthin improves stem cell potency via an increase in the proliferation of neural progenitor cells," International Journal of Molecular Sciences, vol. 11, no. 12, pp. 5109-5119, 2010.

[35] A. R. Rao, R. Sarada, M. D. Shylaja, and G. A. Ravishankar, "Evaluation of hepatoprotective and antioxidant activity of astaxanthin and astaxanthin esters from microalgaHaematococcus pluvialis," Journal of Food Science and Technology, vol. 52, no. 10, pp. 6703-6710, 2015.

[36] M. Zuluaga, A. Barzegari, D. Letourneur, V. Gueguen, and G. Pavon-Djavid, "Oxidative stress regulation on endothelial cells by hydrophilic Astaxanthin complex: chemical, biological, and molecular antioxidant activity evaluation," Oxidative Medicine and Cellular Longevity, vol. 2017, Article ID 8073798, 15 pages, 2017.

[37] S. Davinelli, M. E. Nielsen, and G. Scapagnini, "Astaxanthin in skin health, repair, and disease: a comprehensive review," Nutrients, vol. 10, no. 4, p. 522, 2018.

[38] X. Liu, Q. Luo, K. Rakariyatham et al., “Antioxidation and anti-ageing activities of different stereoisomeric astaxanthin in vitro and in vivo," Journal of Functional Foods, vol. 25, pp. 50-61, 2016.

[39] J. Huangfu, J. Liu, Z. Sun et al., "Antiaging effects of astaxanthin-rich Alga Haematococcus pluvialis on fruit flies under oxidative stress," Journal of Agricultural and Food Chemistry, vol. 61, no. 32, pp. 7800-7804, 2013.

[40] M. Balietti, S. R. Giannubilo, B. Giorgetti et al., "The effect of astaxanthin on the aging rat brain: gender-related differences in modulating inflammation," Journal of the Science of Food and Agriculture, vol. 96, no. 2, pp. 615-618, 2016.

[41] J. Wang, S. Liu, H. Wang et al., "Xanthophyllomyces dendrorhous-derived astaxanthin regulates lipid metabolism and gut microbiota in obese mice induced by a high-fat diet," Marine Drugs, vol. 17, no. 6, p. 337, 2019.

[42] A. A. Dayem, M. Hossain, S. Lee et al., "The role of reactive oxygen species (ROS) in the biological activities of metallic nanoparticles," International Journal of Molecular Sciences, vol. 18, no. 1, pp. 120-121, 2017.

[43] H. Sies and D. P. Jones, "Reactive oxygen species (ROS) as pleiotropic physiological signalling agents," Nature Reviews Molecular Cell Biology, vol. 21, no. 7, pp. 363-383, 2020.
[44] P. D. Ray, B. W. Huang, and Y. Tsuji, "Reactive oxygen species (ROS) homeostasis and redox regulation in cellular signaling," Cellular Signalling, vol. 24, no. 5, pp. 981-990, 2012.

[45] W. Stahl and H. Sies, "Antioxidant activity of carotenoids," Molecular Aspects of Medicine, vol. 24, no. 6, pp. 345-351, 2003.

[46] K. Jørgensen and L. Skibsted, "H. Carotenoid scavenging of radicals. Effect of carotenoid structure and oxygen partial pressure on antioxidative activity. Z. Lebensm. Unters," Forschung, vol. 196, pp. 423-429, 1993.

[47] W. Miki, "Biological functions and activities of animal carotenoids," Pure and Applied Chemistry, vol. 63, no. 1, pp. 141146, 1991.

[48] A. R. Domínguez-Bocanegra, I. Guerrero Legarreta, F. Martinez Jeronimo, and A. Tomasini Campocosio, "Influence of environmental and nutritional factors in the production of astaxanthin from Haematococcus pluvialis," Bioresource Technology, vol. 92, pp. 209-214, 2004.

[49] Y.-K. Lee and C.-W. Soh, "Accumulation of Astaxanthin in Haematococcus lacustris (Chlorophyta)," Journal of Phycology, vol. 27, no. 5, pp. 575-577, 1991.

[50] M. Orosa, J. F. Valero, C. Herrero, and J. Abalde, "Comparison of the accumulation of astaxanthin in Haematococcus pluvialis and other green microalgae under $\mathrm{N}$-starvation and high light conditions," Biotechnology Letters, vol. 23, no. 13, pp. 1079-1085, 2001.

[51] D. H. Zhang and Y. K. Lee, "Enhanced accumulation of secondary carotenoids in a mutant of the green alga, Chlorococcum sp.", Journal of Applied Phycology, vol. 9, no. 5, pp. 459463, 1997.

[52] J.-h. Chen, D. Wei, and P. E. Lim, "Enhanced coproduction of astaxanthin and lipids by the green microalga Chromochloris zofingiensis: Selected phytohormones as positive stimulators," Bioresource Technology, vol. 295, article 122242, 2020.

[53] M. Grung and S. Liaaen-Jensen, "Algal carotenoids 52*; secondary carotenoids of algae 3 ; carotenoids in a natural bloom of Euglena sanguinea," Biochemical Systematics and Ecology, vol. 21, no. 8, pp. 757-763, 1993.

[54] F. Sommer, C. Agurto, P. Henriksen, and T. Kiørboe, "Astaxanthin in the calanoid copepod Calanus helgolandicus: dynamics of esterification and vertical distribution in the German bight, North Sea," Marine Ecology Progress Series, vol. 319, pp. 167-173, 2006.

[55] M. Lotocka and E. Styczyńska-Jurewicz, "Astaxanthin, canthaxanthin and astaxanthin esters in the copepod Acartia bifilosa (Copepoda, Calanoida) during ontogenetic development," Oceanologia, vol. 43, pp. 487-497, 2001.

[56] S. Hylander, T. Kiørboe, P. Snoeijs, R. Sommaruga, and T. Nielsen, "Concentrations of sunscreens and antioxidant pigments in A rctic C alanus spp. in relation to ice cover, ultraviolet radiation, and the phytoplankton spring bloom," Oceanography, vol. 60, no. 6, pp. 2197-2206, 2015.

[57] W. Yu and J. Liu, "Astaxanthin isomers: Selective distribution and isomerization in aquatic animals," Aquaculture, vol. 520, article 734915, Article ID 10.1016/j.aquaculture.2019.734915, 2019.

[58] A. R. Juhl, M. D. Ohman, and R. Goericke, "Astaxanthin in Calanus pacificus: assessment of pigment-based measures of omnivory," Limnology and Oceanography, vol. 41, no. 6, pp. 1198-1207, 1996. 
[59] M. J. Caramujo, C. C. C. R. De Carvalho, S. J. Silva, and K. R. Carman, "Dietary carotenoids regulate astaxanthin content of copepods and modulate their susceptibility to UV light and copper toxicity," Marine Drugs, vol. 10, no. 12, pp. 998-1018, 2012

[60] M. ŁOtocka, E. Styczyńska-Jurewicz, and L. A. BŁȩdzki, "Changes in carotenoid composition in different developmental stages of copepods: Pseudocalanus acuspes Giesbrecht and Acartia spp," Journal of Plankton Research, vol. 26, no. 2, pp. 159-166, 2004.

[61] P. J. Herring, "Pigmentation and carotenoid metabolism of the marine isopodIdotea metallica," Journal of the Marine Biological Association of the United Kingdom, vol. 49, no. 3, pp. 767-779, 1969.

[62] A. Yokoyama, H. Izumida, and W. Miki, "Production of astaxanthin and 4-ketozeaxanthin by the marine bacterium, agrobacterium aurantiacum," Bioscience, Biotechnology, and Biochemistry, vol. 58, pp. 1842-1844, 2014.

[63] D. Asker, "Isolation and characterization of a novel, highly selective Astaxanthin-producing marine bacterium," Journal of Agricultural and Food Chemistry, vol. 65, no. 41, pp. 9101-9109, 2017.

[64] M. Shahina, A. Hameed, S. Y. Lin et al., "Sphingomicrobium astaxanthinifaciens sp. nov., an astaxanthin-producing glycolipid-rich bacterium isolated from surface seawater and emended description of the genus Sphingomicrobium," International Journal of Systematic and Evolutionary Microbiology, vol. 63, Part 9, pp. 3415-3422, 2013.

[65] G. O. Osanjo, E. W. Muthike, L. Tsuma et al., "A salt lake extremophile, Paracoccus bogoriensis sp nov., efficiently produces xanthophyll carotenoids," African Journal of Microbiology Research, vol. 3, pp. 426-433, 2009.

[66] J.-L. Barredo, "Microbial carotenoids from Bacteria and microalgae," Methods and Protocols, vol. 892, 2012.

[67] M. Matsumoto, D. Iwama, A. Arakaki et al., "Altererythrobacter ishigakiensis sp. nov., an astaxanthin-producing bacterium isolated from a marine sediment," International Journal of Systematic and Evolutionary Microbiology, vol. 61, no. 12, pp. 2956-2961, 2011.

[68] J. H. Lee, Y. S. Kim, T. J. Choi, W. J. Lee, and Y. T. Kim, "Paracoccus haeundaensis sp. nov., a Gram-negative, halophilic, astaxanthin-producing bacterium," International Journal of Systematic and Evolutionary Microbiology, vol. 54, no. 5, pp. 1699-1702, 2004.

[69] A. Tsubokura, H. Yoneda, and H. Mizuta, "Paracoccus carotinifaciens sp. nov., a new aerobic gram-negative astaxanthin-producing bacterium," International Journal of Systematic and Evolutionary Microbiology, vol. 49, no. 1, pp. 277-282, 1999.

[70] E. Kusdiyantini, P. Gaudin, G. Goma, and P. J. Blanc, "Growth kinetics and astaxanthin production of Phaffia rhodozyma on glycerol as a carbon source during batch fermentation," Biotechnology Letters, vol. 20, no. 10, pp. 929-934, 1998.

[71] E. A. Johnson and M. J. Lewis, "Astaxanthin formation by the yeast Phaffia rhodozyma," Journal of General Microbiology, vol. 115, no. 1, pp. 173-183, 1979.

[72] Y. Miura, K. Kondo, T. Saito, H. Shimada, P. D. Fraser, and N. Misawa, "Production of the carotenoids lycopene, $\beta$-carotene, and astaxanthin in the food yeast Candida utilis," Applied and Environmental Microbiology, vol. 64, no. 4, pp. 1226-1229, 1998.
[73] P. Calo, T. Miguelde, C. Sieiro, J. B. Velasquez, and T. G. Vilia, "Ketocarotenoids in halobacteria: 3-hydroxyechinenone and trans-astaxanthin," Journal of Applied Bacteriology, vol. 79, no. 3, pp. 282-285, 1995.

[74] Y. Yamaoka, "Microorganism and production of carotinoid compounds thereby," US Patent. US 7,374,908 B2, 2008.

[75] Y. H. Chien and W. C. Shiau, "The effects of dietary supplementation of algae and synthetic astaxanthin on body astaxanthin, survival, growth, and low dissolved oxygen stress resistance of kuruma prawn, Marsupenaeus japonicus Bate," Journal of Experimental Marine Biology and Ecology, vol. 318, no. 2, pp. 201-211, 2005.

[76] J. Pu, P. J. Bechtel, and S. Sathivel, "Extraction of shrimp astaxanthin with flaxseed oil: effects on lipid oxidation and astaxanthin degradation rates," Biosystems Engineering, vol. 107, no. 4, pp. 364-371, 2010.

[77] R. Armenta-Lopez, L. I. Guerrero, and S. Huerta, "Astaxanthin Extraction From Shrimp Waste by Lactic Fermentation and Enzymatic Hydrolysis of the Carotenoprotein Complex," Journal of Food Science, vol. 67, no. 3, pp. 10021006, 2002.

[78] J. Parisenti, L. H. Beirão, M. Maraschin et al., "Pigmentation and carotenoid content of shrimp fed with Haematococcus pluvialis and soy lecithin," Aquaculture Nutrition, vol. 17, no. 2, pp. e530-e535, 2011.

[79] C. H. Pan and Y. H. Chien, "Concentration and composition of astaxanthin in black tiger prawn penaeus monodon postlarvae fed Artemia sp. Nauplii or mauxia Shrimsp acetes intermedius," Journal of the World Aquaculture Society, vol. 34, no. 1, pp. 57-65, 2003.

[80] F. Visioli and C. Artaria, "Astaxanthin in cardiovascular health and disease: mechanisms of action, therapeutic merits, and knowledge gaps," Food \& Function, vol. 8, no. 1, pp. 3963, 2017.

[81] I. Higuera-Ciapara, L. Félix-Valenzuela, and F. M. Goycoolea, "Astaxanthin: a review of its chemistry and applications," Critical Reviews in Food Science and Nutrition, vol. 46, no. 2, pp. 185-196, 2006.

[82] D. J. Charest, M. O. Balaban, M. R. Marshall, and J. A. Cornell, "Astaxanthin extraction from crawfish shells by supercritical $\mathrm{CO}_{2}$ with ethanol as Cosolvent," Journal of Aquatic Food Product Technology, vol. 10, no. 3, pp. 81-96, 2001.

[83] G. N. Coral-Hinostroza and B. Bjerkeng, "Astaxanthin from the red crab langostilla (Pleuroncodes planipes): optical $R / S$ isomers and fatty acid moieties of astaxanthin esters," Comparative Biochemistry and Physiology Part B: Biochemistry and Molecular Biology, vol. 133, no. 3, pp. 437-444, 2002.

[84] Z. Wang, C.-f. Cai, X.-m. Cao et al., "Supplementation of dietary astaxanthin alleviated oxidative damage induced by chronic high $\mathrm{pH}$ stress, and enhanced carapace astaxanthin concentration of Chinese mitten crab Eriocheir sinensis," Aquaculture, vol. 483, pp. 230-237, 2018.

[85] L. Auerswald and G. Gäde, "The west coast rock lobsterJasus lalandiias a valuable source for chitin and astaxanthin," African Journal of Marine Science, vol. 27, no. 1, pp. 257-264, 2005.

[86] K. C. Lim, F. M. Yusoff, M. Shariff, and M. S. Kamarudin, "Astaxanthin as feed supplement in aquatic animals," Reviews in Aquaculture, vol. 10, pp. 738-773, 2018.

[87] M. Andersson, L. Van Nieuwerburgh, and P. Snoeijs, "Pigment transfer from phytoplankton to zooplankton with 
emphasis on astaxanthin production in the Baltic Sea food web," Marine Ecology Progress Series, vol. 254, pp. 213-224, 2003.

[88] Marine Harvest, Salmon Farming Industry Handbook 2019, 2016.

[89] L. G. Buttle, V. O. Crampton, and P. D. Williams, "The effect of feed pigment type on flesh pigment deposition and colour in farmed Atlantic salmon, Salmo salar L," Aquaculture Research, vol. 32, no. 2, pp. 103-111, 2001.

[90] S. J. Lehnert, K. A. Christensen, W. E. Vandersteen et al., "Carotenoid pigmentation in salmon: variation in expression at $B C O 2-l$ locus controls a key fitness trait affecting red coloration," Proceedings of the Royal Society B: Biological Sciences, vol. 286, no. 1913, p. 20191588, 2019.

[91] P. A. Megdal, N. A. Craft, and G. J. Handelman, “A simplified method to distinguish farmed (Salmo salar) from wild salmon: fatty acid ratios versus astaxanthin chiral isomers," Lipids, vol. 44, no. 6, pp. 569-576, 2009.

[92] M. M. R. Shah, Y. Liang, J. J. Cheng, and M. Daroch, “Astaxanthin-producing green microalga Haematococcus pluvialis: from single cell to high value commercial products," Frontiers in Plant Science, vol. 7, 2016.

[93] T. Brendler and E. M. Williamson, "Astaxanthin: how much is too much? A safety review," Phytotherapy Research, vol. 33, no. 12, pp. 3090-3111, 2019.

[94] A. Udayan, M. Arumugam, and A. Pandey, "Chapter 4 Nutraceuticals," in Algae and Cyanobacteria, R. P. Rastogi, D. Madamwar, and A. B. T.-A. G. C. Pandey, Eds., pp. 6589, Elsevier, Amsterdam, 2017.

[95] M. Østerlie, B. Bjerkeng, and S. Liaaen-Jensen, “Accumulation of Astaxanthin all-E, $9 \mathrm{Z}$ and $13 \mathrm{Z}$ geometrical isomers and 3 and $3^{\prime} R S$ optical isomers in rainbow trout (Oncorhynchus mykiss) is selective," The Journal of Nutrition, vol. 129, no. 2, pp. 391-398, 1999.

[96] B. Bjerkeng, M. Følling, S. Lagocki, T. Storebakken, J. J. Olli, and N. Alsted, "Bioavailability of all-E-astaxanthin and Z-isomers of astaxanthin in rainbow trout (Oncorhynchus mykiss)," Aquaculture, vol. 157, no. 1-2, pp. 63-82, 1997.

[97] F. Su and J. Liu, "The carotenoid characteristics of the important wild shrimp Trachysalambria curvirostris (Stimpson, 1860) in China," Journal of Oceanology and Limnology, vol. 37, no. 2, pp. 706-712, 2019.

[98] F. Su, B. Huang, and J. Liu, "The carotenoids of shrimps (Decapoda: Caridea and Dendrobranchiata) cultured in China," Journal of Crustacean Biology, vol. 38, no. 5, pp. 523-530, 2018.

[99] J. Yuan and F. Chen, "Isomerization of trans-Astaxanthin to cis-Isomers in organic solvents," Journal of Agricultural and Food Chemistry, vol. 47, no. 9, pp. 3656-3660, 1999.

[100] J. P. Yuan and F. Chen, "Kinetics for the reversible isomerization reaction of trans-astaxanthin," Food Chemistry, vol. 73, no. 2, pp. 131-137, 2001.

[101] L. Zhao, G. Zhao, F. Chen, Z. Wang, J. Wu, and X. Hu, "Different effects of microwave and ultrasound on the stability of (all-E)-astaxanthin," Journal of Agricultural and Food Chemistry, vol. 54, no. 21, pp. 8346-8351, 2006.

[102] W. J. C. De Bruijn, Y. Weesepoel, J. P. Vincken, and H. Gruppen, "Fatty acids attached to all-trans-astaxanthin alter its cis-trans equilibrium, and consequently its stability, upon light-accelerated autoxidation," Food Chemistry, vol. 194, pp. 1108-1115, 2016.
[103] L. Zhao, F. Chen, G. Zhao, Z. Wang, X. Liao, and X. Hu, "Isomerization of trans-Astaxanthin induced by copper(II) ion in ethanol," Journal of Agricultural and Food Chemistry, vol. 53, no. 24, pp. 9620-9623, 2005.

[104] C. Köpsel, H. Möltgen, H. Schuch et al., "Structure investigations on assembled astaxanthin molecules," Journal of Molecular Structure, vol. 750, no. 1-3, pp. 109-115, 2005.

[105] M. Fuciman, M. Durchan, V. Šlouf, G. Keşan, and T. Polívka, "Excited-state dynamics of astaxanthin aggregates," Chemical Physics Letters, vol. 568-569, pp. 21-25, 2013.

[106] R. Giovannetti, L. Alibabaei, and F. Pucciarelli, "Kinetic model for astaxanthin aggregation in water-methanol mixtures," Spectrochimica Acta Part A: Molecular and Biomolecular Spectroscopy, vol. 73, pp. 157-162, 2009.

[107] L. Lu, T. Hu, and Z. Xu, "Structural characterization of astaxanthin aggregates as revealed by analysis and simulation of optical spectra," Spectrochimica Acta Part A: Molecular and Biomolecular Spectroscopy, vol. 185, pp. 85-92, 2017.

[108] G. Zajac, E. Machalska, A. Kaczor, J. Kessler, P. Bouř, and M. Baranska, "Structure of supramolecular astaxanthin aggregates revealed by molecular dynamics and electronic circular dichroism spectroscopy," Physical Chemistry Chemical Physics, vol. 20, no. 26, pp. 18038-18046, 2018.

[109] N. E. Polyakov, A. Magyar, and L. D. Kispert, "Photochemical and optical properties of water-soluble xanthophyll antioxidants: aggregation vs complexation," Journal of Physical Chemistry B, vol. 117, no. 35, pp. 10173-10182, 2013.

[110] M. Østerlie, B. Bjerkeng, and S. Liaaen-Jensen, "Plasma appearance and distribution of astaxanthin $E / Z$ and $R / S$ isomers in plasma lipoproteins of men after single dose administration of astaxanthin ${ }^{1}$," The Journal of Nutritional Biochemistry, vol. 11, no. 10, pp. 482-490, 2000.

[111] C. E. Rüfer, J. Moeseneder, K. Briviba, G. Rechkemmer, and A. Bub, "Bioavailability of astaxanthin stereoisomers from wild (Oncorhynchus spp.) and aquacultured (Salmo salar) salmon in healthy men: a randomised, double-blind study," British Journal of Nutrition, vol. 99, no. 5, pp. 1048-1054, 2008.

[112] C. Yang, H. Zhang, R. Liu, H. Zhu, L. Zhang, and R. Tsao, "Bioaccessibility, cellular uptake, and transport of Astaxanthin isomers and their Antioxidative effects in human intestinal epithelial Caco-2 cells," Journal of Agricultural and Food Chemistry, vol. 65, no. 47, pp. 10223-10232, 2017.

[113] R. M. Trüeb, “The impact of oxidative stress on hair," International Journal of Cosmetic Science, vol. 37, pp. 25-30, 2015.

[114] A. P. Anderson, X. Luo, W. Russell, and Y. W. Yin, "Oxidative damage diminishes mitochondrial DNA polymerase replication fidelity," Nucleic Acids Research, vol. 48, no. 2, pp. 817-829, 2020.

[115] J. Kruk, H. Y. Aboul-Enein, A. Kladna, and J. E. Bowser, "Oxidative stress in biological systems and its relation with pathophysiological functions: the effect of physical activity on cellular redox homeostasis," Free Radical Research, vol. 53, no. 5, pp. 497-521, 2019.

[116] E. B. Kurutas, "The importance of antioxidants which play the role in cellular response against oxidative/nitrosative stress: current state," Nutrition Journal, vol. 15, pp. 1-22, 2015.

[117] A. Galano, "Free Radicals Induced Oxidative Stress at a Molecular Level: The Current Status, Challenges and Perspectives of Computational Chemistry Based Protocols," 
Journal of the Mexican Chemical Society, vol. 59, no. 4, pp. 231-262, 2017.

[118] B. Halliwell and J. M. C. Gutteridge, Free Radicals in Biology and Medicine, Oxford University Press, Oxford, 5th edition, 2015.

[119] M. D. Brand, "Mitochondrial generation of superoxide and hydrogen peroxide as the source of mitochondrial redox signaling," Free Radical Biology and Medicine, vol. 100, pp. 1431, 2016.

[120] T. D. Oury, J. D. Crapo, Z. Valnickova, and J. J. Enghild, "Human extracellular superoxide dismutase is a tetramer composed of two disulphide-linked dimers: a simplified, high-yield purification of extracellular superoxide dismutase," The Biochemical Journal, vol. 317, no. 1, pp. 51-57, 1996.

[121] B. A. Stanley, V. Sivakumaran, S. Shi et al., "Thioredoxin reductase-2 is essential for keeping low levels of $\mathrm{H}_{2} \mathrm{O}_{2}$ Emission from isolated heart mitochondria," Journal of Biological Chemistry, vol. 286, no. 38, pp. 33669-33677, 2011.

[122] A. P. Kudin, B. Augustynek, A. K. Lehmann, R. Kovács, and W. S. Kunz, "The contribution of thioredoxin-2 reductase and glutathione peroxidase to $\mathrm{H}_{2} \mathrm{O}_{2}$ detoxification of rat brain mitochondria," Biochimica et Biophysica Acta (BBA) Bioenergetics, vol. 1817, no. 10, pp. 1901-1906, 2012.

[123] Y. Peng, C. Wang, H. H. Xu, Y. N. Liu, and F. Zhou, "Binding of $\alpha$-synuclein with $\mathrm{Fe}(\mathrm{III})$ and with $\mathrm{Fe}(\mathrm{II})$ and biological implications of the resultant complexes," Journal of Inorganic Biochemistry, vol. 104, no. 4, pp. 365-370, 2010.

[124] F. Collin, "Chemical basis of reactive oxygen species reactivity and involvement in neurodegenerative diseases," International Journal of Molecular Sciences, vol. 20, no. 10, article 2407, 2019.

[125] J. P. Kehrer, "The Haber-Weiss reaction and mechanisms of toxicity," Toxicology, vol. 149, no. 1, pp. 43-50, 2000.

[126] P. Wardman, "Reduction potentials of one Electron couples involving free radicals in aqueous solution," Journal of Physical and Chemical Reference Data, vol. 18, no. 4, pp. 16371755, 1989.

[127] G. V. Buxton, C. L. Greenstock, W. P. Helman, and A. B. Ross, "Critical review of rate constants for reactions of hydrated electrons, hydrogen atoms and hydroxyl radicals (.OH/.O-) in aqueous solution," Journal of Physical and Chemical Reference Data, vol. 17, no. 2, pp. 513-886, 1988.

[128] P. Neta, R. E. Huie, and A. B. Ross, "Rate constants for reactions of Peroxyl radicals in fluid solutions," Journal of Physical and Chemical Reference Data, vol. 19, no. 2, pp. 413-513, 1990.

[129] S. Goto, K. Kogure, K. Abe et al., "Efficient radical trapping at the surface and inside the phospholipid membrane is responsible for highly potent antiperoxidative activity of the carotenoid astaxanthin," Biochimica et Biophysica Acta (BBA) Biomembranes, vol. 1512, no. 2, pp. 251-258, 2001.

[130] A. Mortensen, L. H. Skibsted, J. Sampson, C. Rice-Evans, and S. A. Everett, "Comparative mechanisms and rates of free radical scavenging by carotenoid antioxidants," FEBS Letters, vol. 418, no. 1-2, pp. 91-97, 1997.

[131] R. Edge, D. J. McGarvey, and T. G. Truscott, “The carotenoids as anti-oxidants - a review," Journal of Photochemistry and Photobiology B: Biology, vol. 41, no. 3, pp. 189-200, 1997.

[132] A. J. Young and G. M. Lowe, "Antioxidant and prooxidant properties of carotenoids," Archives of Biochemistry and Biophysics, vol. 385, no. 1, pp. 20-27, 2001.
[133] A. A. Woodall, S. W. M. Lee, R. J. Weesie, M. J. Jackson, and G. Britton, "Oxidation of carotenoids by free radicals: relationship between structure and reactivity," Biochimica et Biophysica Acta (BBA) - General Subjects, vol. 1336, no. 1, pp. 33-42, 1997.

[134] R. M. Han, J. P. Zhang, and L. H. Skibsted, "Reaction dynamics of flavonoids and carotenoids as antioxidants," Molecules, vol. 17, no. 2, pp. 2140-2160, 2012.

[135] A. L. Focsan, N. E. Polyakov, and L. D. Kispert, "Photo protection of haematococcus pluvialis algae by astaxanthin: unique properties of astaxanthin deduced by epr, optical and electrochemical studies," Antioxidants, vol. 6, no. 4, p. 80, 2017.

[136] E. Rodrigues, L. R. B. Mariutti, and A. Z. Mercadante, "Scavenging capacity of marine carotenoids against reactive oxygen and nitrogen species in a membrane-mimicking system," Marine Drugs, vol. 10, pp. 1784-1798, 2012.

[137] J. Zhang, Z. Sun, P. Sun, T. Chen, and F. Chen, "Microalgal carotenoids: beneficial effects and potential in human health," Food \& Function, vol. 5, no. 3, pp. 413-425, 2014.

[138] Y. M. A. Naguib, "Antioxidant activities of astaxanthin and related carotenoids," Journal of Agricultural and Food Chemistry, vol. 48, no. 4, pp. 1150-1154, 2000.

[139] A. L. Focsan, S. Pan, and L. D. Kispert, "Electrochemical study of astaxanthin and Astaxanthinn-Octanoic monoester and diester: tendency to form radicals," The Journal of Physical Chemistry B, vol. 118, no. 9, pp. 2331-2339, 2014.

[140] N. E. Polyakov, A. I. Kruppa, T. V. Leshina, T. A. Konovalova, and L. D. Kispert, "Carotenoids as antioxidants: spin trapping EPR andoptical study," Free Radical Biology and Medicine, vol. 31, no. 1, pp. 43-52, 2001.

[141] H. Hashimoto, K. Arai, S. Hayashi, H. Okamoto, and J. Takahashi, "Isoflavone intake inhibits the development of 7,12-dimethylbenz(a)anthracene(DMBA)-induced mammary tumors in normal and ovariectomized rats," Journal of Clinical Biochemistry and Nutrition, vol. 54, pp. 31-38, 2014.

[142] M. Kobayashi and Y. Sakamoto, "Singlet oxygen quenching ability of astaxanthin esters from the green alga Haematococcus pluvialis," Biotechnology Letters, vol. 21, no. 4, pp. 265269, 1999.

[143] A. Ouchi, K. Aizawa, Y. Iwasaki et al., "Kinetic study of the quenching reaction of singlet oxygen by carotenoids and food extracts in solution. Development of a singlet oxygen absorption capacity (SOAC) assay method," Journal of Agricultural and Food Chemistry, vol. 58, pp. 9967-9978, 2010.

[144] F. Böhm, R. Edge, and G. Truscott, "Interactions of dietary carotenoids with activated (singlet) oxygen and free radicals: potential effects for human health," Molecular Nutrition \& Food Research, vol. 56, no. 2, pp. 205-216, 2012.

[145] R. Edge and T. George Truscott, "Carotenoid Radicals and the Interaction of Carotenoids with Active Oxygen Species," in The Photochemistry of Carotenoids, Advances in Photosynthesis and Respiration, H. A. Frank, A. J. Young, G. Britton, and R. J. Cogdell, Eds., pp. 223-234, Springer, Dordrecht, 1999.

[146] G. Sandmann, "Antioxidant protection from UV- and lightstress related to carotenoid structures," Antioxidants, vol. 8, no. 7, p. 219, 2019.

[147] B. R. Nielsen, K. Jørgensen, and L. H. Skibsted, “Triplet-triplet extinction coefficients, rate constants of triplet decay and rate constant of anthracene triplet sensitization by laser flash 
photolysis of astaxanthin, $\beta$-carotene, canthaxanthin and zeaxanthin in deaerated toluene at $298 \mathrm{~K}$," Journal of Photochemistry and Photobiology A: Chemistry, vol. 112, no. 2-3, pp. 127-133, 1998.

[148] H. Tamura, H. Ishikita, and J. Accepted, "Quenching of singlet oxygen by carotenoids via ultrafast super-exchange dynamics," The Journal of Physical Chemistry A, vol. 124, no. 25, pp. 5081-5088, 2020.

[149] K. Yazaki, C. Yoshikoshi, S. Oshiro, and S. Yanase, "Supplemental cellular protection by a carotenoid extends lifespan via ins/IGF-1 signaling in caenorhabditis elegans," Oxidative Medicine and Cellular Longevity, vol. 2011, 9 pages, 2011.

[150] A. Cantrell, D. J. McGarvey, T. G. Truscott, F. Rancan, and F. Böhm, "Singlet oxygen quenching by dietary carotenoids in a model membrane environment," Archives of Biochemistry and Biophysics, vol. 412, no. 1, pp. 47-54, 2003.

[151] K. Fukuzawa, Y. Inokami, A. Tokumura, J. Terao, and A. Suzuki, "Rate constants for quenching singlet oxygen and activities for inhibiting lipid peroxidation of carotenoids and $\alpha$-tocopherol in liposomes," Lipids, vol. 33, no. 8, pp. 751-756, 1998.

[152] P. F. Conn, W. Schalch, and T. G. Truscott, "The singlet oxygen and carotenoid interaction," Journal of Photochemistry and Photobiology B: Biology, vol. 11, no. 1, pp. 41-47, 1991.

[153] K. Mukai, A. Ouchi, N. Azuma, S. Takahashi, K. Aizawa, and S. Nagaoka, "Development of a singlet oxygen absorption capacity (SOAC) assay method. Measurements of the SOAC values for carotenoids and $\alpha$-tocopherol in an aqueous triton X-100 micellar solution," Journal of Agricultural and Food Chemistry, vol. 65, no. 4, pp. 784-792, 2017.

[154] Y. Iwasaki, S. Takahashi, K. Aizawa, and K. Mukai, "Development of singlet oxygen absorption capacity (SOAC) assay method. 4. Measurements of the SOAC values for vegetable and fruit extracts," Bioscience, Biotechnology, and Biochemistry, vol. 79, pp. 280-291, 2014.

[155] P. Di Mascio, S. Kaiser, and H. Sies, "Lycopene as the most efficient biological carotenoid singlet oxygen quencher," Archives of Biochemistry and Biophysics, vol. 274, no. 2, pp. 532-538, 1989.

[156] N. Shimidzu, M. Goto, and W. Miki, "Carotenoids as singlet oxygen quenchers in marine organisms," Fisheries Science, vol. 62, no. 1, pp. 134-137, 1996.

[157] A. Kumbhar, S. Padhye, and D. Ross, "Cytotoxic properties of iron-hydroxynaphthoquinone complexes in rat hepatocytes," Biometals, vol. 9, no. 3, pp. 235-240, 1996.

[158] N. Gokhale, S. Padhye, C. Newton, and R. Pritchard, "Hydroxynaphthoquinone metal complexes as antitumor agents $\mathrm{X}$ : synthesis, structure, spectroscopy and in vitro antitumor activity of 3-methyl-phenylazo lawsone derivatives and their metal complexes against human breast cancer cell line MCF-7," Metal-Based Drugs, vol. 7, no. 3, 128 pages, 2000.

[159] V. A. Timoshnikov, T. V. Kobzeva, N. E. Polyakov, and G. J. Kontoghiorghes, "Inhibition of $\mathrm{Fe}^{2+}$ - and $\mathrm{Fe}^{3+}$ - induced hydroxyl radical production by the iron-chelating drug deferiprone," Free Radical Biology and Medicine, vol. 78, pp. 118$122,2015$.

[160] E. Hernández-Marin, A. Barbosa, and A. Martínez, “The metal cation chelating capacity of astaxanthin. Does this have any influence on antiradical activity?," Molecules, vol. 17, no. 1, pp. 1039-1054, 2012.
[161] N. E. Polyakov, A. L. Focsan, M. K. Bowman, and L. D. Kispert, "Free radical formation in novel carotenoid metal ion complexes of astaxanthin," Journal of Physical Chemistry B, vol. 114, no. 50, pp. 16968-16977, 2010

[162] E. Rodrigues, L. R. B. Mariutti, R. C. Chisté, and A. Z. Mercadante, "Development of a novel micro-assay for evaluation of peroxyl radical scavenger capacity: application to carotenoids and structure-activity relationship," Food Chemistry, vol. 135, no. 3, pp. 2103-2111, 2012.

[163] X. Liu and T. Osawa, "Cis astaxanthin and especially 9-cis astaxanthin exhibits a higher antioxidant activity in vitro compared to the all-trans isomer," Biochemical and Biophysical Research Communications, vol. 357, no. 1, pp. 187-193, 2007.

[164] C. Yang, L. Zhang, H. Zhang et al., "Rapid and efficient conversion of all- $E$-astaxanthin to $9 Z$ - and $13 Z$-isomers and assessment of their stability and antioxidant activities," Journal of Agricultural and Food Chemistry, vol. 65, no. 4, pp. 818-826, 2017.

[165] S. Chintong, W. Phatvej, U. Rerk-Am, Y. Waiprib, and W. Klaypradit, "In vitro antioxidant, antityrosinase, and cytotoxic activities of astaxanthin from Shrimp Waste," Antioxidants, vol. 8, no. 5, p. 128, 2019.

[166] I. Santhose and R. Kanna, "Antioxidant and anti-skin cancer potential of a Ketocarotenoid pigment Astaxanthin isolated from a green microalga Haematococcus pluvialis Flotow," International Journal of Scientific and Engineering Research, vol. 7, pp. 902-916, 2016.

[167] L. Müller, K. Fröhlich, and V. Böhm, "Comparative antioxidant activities of carotenoids measured by ferric reducing antioxidant power (FRAP), ABTS bleaching assay ( $\alpha$ TEAC), DPPH assay and peroxyl radical scavenging assay," Food Chemistry, vol. 129, no. 1, pp. 139-148, 2011. 